Janina Kostkiewicz

Uniwersytet Jagielloński

\title{
HUMANISTYCZNA PEDAGOGIKA SPOŁECZNA JAKO POGRANICZE I OBSZAR WSPÓLNY Z KATOLICKĄ NAUKĄ SPOŁECZNA. SZKIC ZAGADNIENIA
}

\author{
Humanistic social pedagogy as a borderland and a common area with Catholic social \\ teachings. A sketch of the issue
}

\begin{abstract}
Summary: The purpose of this article is to take a step towards returning to social pedagogy those areas of educational practice and theory that were built on the borderlands between pedagogy and Catholic social teachings. This constitutes a humanistic social pedagogy. This endeavor is important, as it has been argued that pedagogues have lost their influence on this particular pedagogy, a pedagogy that influences social life and national culture in both theory and practice. Both historians of education and contemporary pedagogues have failed to take meaningful notice of the output, traditions and value of this unique relationship. This brief sketch is intended to encourage the more complete reconstruction of humanistic social pedagogy.
\end{abstract}

Keywords: humanistic social pedagogy, fields of education, founders of social pedagogy, social education, civic education, political education, pedagogy of borderland

\section{Wstęp}

Humanistyczna pedagogika społeczna jest wymieniana współcześnie wśród kierunków rozwoju pedagogiki społecznej ${ }^{1}$ wynikających $\mathrm{z}$ poszerzonego definiowania jej przedmiotu. Odwołanie się do uznanych jej twórców pozwala pedagogom społecznym rozumieć ją jako „najpierw humanistyczną refleksję o człowieku, środowisku i wielorako uwarunkowanym jego życiu. Stanowi tu integralną część rozważań - raz o zabarwieniu filozoficznym, a innym znowu razem religijnym, etycznym, pedagogicznym albo politycznym, etc. Jako taka ma swoje korzenie, idee - wartości i konteksty, aspekty poznawcze, mądrościowe i życiowe

\footnotetext{
${ }^{1}$ Mariusz Cichosz, Pedagogika spoleczna. Zarys problematyki (Kraków: Oficyna Wydawnicza „Impuls” 2014), 105-108.
} 
odniesienia do wielorakiej ludzkiej egzystencji”2. Jednak w podręcznikach i innych opracowaniach o pedagogice społecznej nie znajdujemy odmiany humanistycznej pedagogiki społecznej mającej źródła religijne, a związanej z katolicką nauką społeczną. Sytuacja ta - zważywszy na dwa tysiąclecia chrześcijaństwa w Europie nie odzwierciedla rzeczywistego stanu rzeczy w nauce i kulturze.

Świadomość istotności kwestii pedagogicznych (wychowawczych) w obrębie katolickiej nauki społecznej nie występuje także u jej reprezentantów. Nie nazywa się tutaj „po imieniu” głównego mechanizmu stojącego u podstaw wdrożenia ich postulatów, którym jest wychowanie (edukacja). Znany podręcznik Czesława Strzeszewskiego Katolicka nauka społeczna ${ }^{3}$ składa się z trzech części: „Podstawy socjologii i ekonomii”, „Historia katolickiej nauki społecznej”, „Katolicka etyka społeczna”. Na tę ostatnią składają się rozdziały: „Podstawowe zasady życia społecznego”; „Życie rodzinne”; „Życie zawodowe”; „Życie społeczno-państwowe”; „Życie międzynarodowe”; „Życie gospodarcze”; „Rozwój społeczny, gospodarczy, kulturalny”. W interdyscyplinarności tej dyscypliny dochodzi do głosu socjologia, ekonomia, etyka, ale nie pedagogika - mimo że wdrażanie katolickiej nauki społecznej zaczyna się od ideałów (celów) życia i wychowania, od podniesienia świadomości człowieka (oraz społeczeństwa), od nabywania wiedzy i wychowania.

Inny podręcznik, Historia katolicyzmu społecznego $w$ Polsce 1832-1939 ${ }^{4}$ także nie eksponuje kwestii pedagogicznych (wychowawczych), mimo że indeks nazwisk tego ogromnego dzieła zawiera autorów wielu prac z dziedziny pedagogiki; prac, w których pedagogika lub wychowanie nie tylko dochodziły do głosu w tytule lub na marginesie zagadnienia, ale były przewodnią kwestią treści dzieła. Przykładowo wymienieni są tam: Zygmunt Balicki, bp. Józef Bilczewski, Edmund Bojanowski, św. Jan Bosco, ks. Jan Ciemniewski, August Cieszkowski, Karol Górski, Jacek Woroniecki OP, bp Michał Klepacz, Józef Kuznowicz SJ, Urszula Ledóchowska, Bronisław Markiewicz CSMA, Andrzej Niesiołowski, ks. Marian Pirożyński, Stanisław Podoleński SJ, Witold Rubczyński, Jan Salamucha, Piotr Semenenko CR, Piotr Smolikowski CR, Jan Urban SJ, Aleksander Wóycicki, Jadwiga Zamoyska, Cecylia Plater-Zyberkówna, Barbara Żulińska CR (wszyscy współtworzą nurt pedagogiki katolickiej), a także inni. Podobnie zamieszczony tam indeks instytucji i czasopism zawiera olbrzymią ilość haseł typowo pedagogicznych: na przykład domy dziecka, przedszkola, szkoły różnego typu, uniwersytety, ochronki, towarzystwa opieki, zakłady wychowawcze; wykazuje też ogromną liczbę stowarzyszeń i organizacji dziecięcych, młodzieżowych oraz dla dorosłych (najczęściej grup zawodowych). Mimo zawartego w tym dziele pedagogicznego wymiaru teorii i praktyki katolicyzmu społecznego (katolickiej nauki społecznej), kwalifikacja pedagogiczna - ani

2 Tadeusz Frąckowiak, O pedagogice nadziei. Fascynacje iasocjacje aksjologiczne (Poznań: Wydawnictwo UAM 2007), 54 .

${ }^{3}$ Czesław Strzeszewski, Katolicka nauka spoleczna (Warszawa: Ośrodek Dokumentacji i Studiów Społecznych 1985).

${ }^{4}$ Historia katolicyzmu spolecznego $w$ Polsce 1832-1939, red. Czesław Strzeszewski i in. (Warszawa: Ośrodek Dokumentacji i Studiów Społecznych 1981). 
w stosunku do teorii, ani do praktyki - nie pojawia się. Podobnie przedstawia się zawartość innych syntez naukowych. Diagnoza powyższa mówi o z a g u b i e n i u w k ła d u p ed a g o g ó w w teorię i praktykę życia społecznego, kultury narodowej. Wkład ten wymyka się nie tylko historykom, ale i współczesnemu dyskursowi odbywającemu się z pominięciem tego pedagogicznego dorobku, tradycji i jej wagi.

Podjęta tu próba spojrzenia na katolicką naukę społeczną jako pogranicze i obszar zawierający humanistyczną pedagogikę społeczną odniesiona będzie do lat 1918-1939. Wynikała ona będzie po części z powszechnej wiedzy o jej wychowawczej (formacyjnej) misji, po części z sytuacji katolickiej nauki społecznej jako dziedziny wiedzy. Z jednej strony powstawała ona równolegle jako socjologia (dookreślana jako socjologia katolicka, chrześcijańska), lecz wskazywanie na jej religijne zakorzenienie sprawiło, że nie „przyjęła się” na uniwersytetach i nie funkcjonuje dziś jako jeden z kierunków rozwoju socjologii. Także akademickie środowiska pedagogów nie widziały w jej obszarze własnego wkładu i kierunku rozwoju. Katolicka nauka społeczna, stojąc na pograniczu tych dwóch młodych dyscyplin (oraz ekonomii i jej etycznych podstaw), zachowała - poprzez swoją identyfikację z aktywnością Kościoła katolickiego - specyfikę i odrębność, stała się też wizytówką jego działalności. Z drugiej jednak strony (z perspektywy nauk: tak pedagogiki, jak i socjologii) sytuacja ta spowodowała zubożenie dorobku (rozwoju) obu dyscyplin, co szczególnie dotyczy teorii i praktyki wychowania społecznego (pedagogiki społecznej) w Polsce. Historia wychowania przedstawiana bez ich obecności nie tylko daje nieprawdziwy obraz obu wymienionych nauk, ale i historii polskiej kultury. Stwarza pozór słabszego niż rzeczywisty, rozwoju subdyscypliny jaką jest pedagogika społeczna (jej teoria i praktyka) w Polsce.

Celem artykułu jest zatem uczynienie kroku w kierunku p r z y w r ó c e n i a pedagogice społecznej obszaru teorii i praktyki wychowawczej, który powstał na pograniczu pedagogiki i katolickiej nauki społecznej. Nie chodzi tu bynajmniej o pomniejszenie obszaru tej drugiej: jej istnienie chroni i zabezpiecza przynależna jej interdyscyplinarność oraz identyfikacja z Kościołem katolickim. Natomiast wskazanie w tym obszarze ewidentnie pedagogicznej teorii i praktyki społecznej wzbogaci historię jej rozwoju, zmieni też stan współczesnej samoświadomości, dyskurs o jej paradygmatach (wydobywając paradygmat obecny, ale nieuznawany), wzmocni ponadto poczucie wolności myślenia i badania naukowego.

Propozycję niniejszą przedstawiam ze świadomością, że obszar pedagogiki społecznej o katolickim rodowodzie w świecie akademickim podlegał dyskryminacji (różnorodnie warunkowanej w różnych okresach czasu), co najczęściej przejawiało się w przemilczaniu faktu jej istnienia, roli i innych. Czym skutkowała ta dyskryminacja - najłatwiej pokazać na przykładzie treści podręczników akademickich (inne jej przejawy wymagają bardziej złożonych uzasadnień). Wiesław Theiss analizował podręczniki pedagogiki społecznej dziesięciu najwybitniejszych twórców z lat 1935-2012 i stwierdził brak choćby podstawowych informacji o pracy społeczno- 
wychowawczej realizowanej w duchu chrześcijańskim przez działaczy katolickich ${ }^{5}$. Dodać należy, że nie tylko PRL, ale także dwudziestolecie międzywojenne nie było wolne od dyskryminacji tego nurtu (aczkolwiek inaczej dochodzącej do głosu) w młodych naukach humanistyczno-społecznych. Po „zmianie “89” stan ten nadal ma miejsce mimo wolności publikacji. Zaistnienie opracowań naukowych pokazujących zarówno teoretyczne, jak i szerokie, różnorodne, twórcze obszary praktyki społecznowychowawczej (przykładowo wymienić tu można prace Wiesława Theissa ${ }^{6}$, Czesława Kustry $^{7}$, Jana Niewęgłowskiego ${ }^{8}$, Mariusza Cichosza ${ }^{9}$, Aliny Rynio ${ }^{10}$, Mariusza Sztaby $^{11}$, Zbigniewa Babickiego ${ }^{12}$, Janiny Kostkiewicz ${ }^{13}$ ) niewiele zmienia w najnowszych ujęciach pedagogiki społecznej ${ }^{14}$.

Uznając potrzebę rekonstrukcji humanistycznej pedagogiki społecznej graniczącej lub/i wchodzącej wobszar katolickiej nauki społecznej, proponuję wyłonić:

a) zarys podstawowych założeń filozoficznych i teologicznych stojących u jej podstaw; b) twórców humanistycznych koncepcji (teorii) wychowania społecznego i głównych jego dziedzin;

c) podmioty prowadzące praktyczną działalność wzakresie pracy społecznowychowawczej (organizacje, stowarzyszenia, ruchy młodzieżowe, ośrodki edukacji dorosłych i wsparcia dla ich działalności zawodowej, ekonomicznej i innej). W niniejszym artykule, ze względu na jego ramy, będą wskazane jedynie wybrane aspekty tych zagadnien.

Realizacja zadań wymienionych wpunktach a-c nie jest działaniem odtwórczym, wymaga badawczego otwarcia na całą rzeczywistość, w której dokonywał się rozwój teorii i praktyki tworzących tę subdyscyplinę. Przede wszystkim jednak zmusza do wychodzenia poza stereotypy myślenia i interpretowania rzeczywistości mocno już wpisane zarówno w metodologię badań społecznych, jak

\footnotetext{
${ }^{5}$ Wiesław Theiss, „Katolicka praca społeczno-wychowawcza. Szkic zagadnienia”. Pedagogika Spoleczna 2 (2013): 47-71.

${ }^{6}$ Tamże. Zob. tegoż, Troska i nadzieja. Działalność spoleczno-wychowawcza ks. Henryka Szumana na Pomorzu w latach 1908-1939 (Toruń: Wydawnictwo Adam Marszałek 2012).

${ }^{7}$ Czesław Kustra, Działalność edukacyjna Towarzystwa „Powściagliwość i Praca” w latach 1898-1949 (Olsztyn: Wyższa Szkoła Informatyki i Ekonomii TWP 2005).

${ }^{8}$ Jan Niewęgłowski, Wychowawczo-spoleczna działalność salezjanów w Polsce w latach 1898-1989 (Warszawa: Wydawnictwo UKSW 2011).

${ }^{9}$ Mariusz Cichosz, Działalność społeczno-wychowawcza Kościoła Katolickiego w środowisku lokalnym (Bydgoszcz: Instytut Wydawniczy „Świadectwo” 1997).

${ }^{10}$ Alina Rynio (wybór i przedmowa). Solidarność w nauczaniu Jana Pawła II. Wybór tekstów (Lublin: Instytut Edukacji Narodowej 2005).

${ }^{11}$ Mariusz Sztaba, Wychowanie społeczne $w$ świetle nauczania Karola Wojtyly Jana Pawta II (Lublin: Towarzystwo Naukowe KUL 2012).

12 Zbigniew Babicki, Społeczno-wychowawcza działalność Księży Pallotynów w Polsce (Ząbki: Apostolicum 2009).

${ }^{13}$ Kostkiewicz, Kierunki i koncepcje, 87-190, 363-460.

${ }^{14} \mathrm{~Np}$. Cichosz, Pedagogika społeczna oraz inne podręczniki wydane w ostatniej dekadzie.
} 
i w dotychczasowy stereotyp budowania wiedzy w pedagogice społecznej. Należy liczyć się z tym, że pojawi się nowa wiedza, niosąca odmienne treści, które będą uzupełniające (także korygujące) w stosunku do wiedzy dotychczasowej.

\section{Elementy teoretycznych podstaw humanistycznej pedagogiki społecznej}

Jak już przyjęliśmy, u podstaw humanistycznej pedagogiki społecznej znajdą się zarówno podstawy katolickiej nauki społecznej, jak i pedagogiki sięgającej do źródeł religii rzymsko-katolickiej z właściwym jej rodzajem humanizmu, który nie „odcina” człowieka od Boga i respektuje jego wymiar duchowy, uwzględnia też pracę nad sobą, samowychowanie i samokształcenie ${ }^{15}$. Był to humanizm wolny od redukcjonizmów wskazywanych przez Jacques'a Martaina, ale także przez Étienne Gilsona czy Romano Guardiniego - w polskiej myśli społeczno-pedagogicznej miał on także swoich przedstawicieli.

\subsection{Humanizm katolickiej nauki społecznej i pedagogiki społecznej}

Katolicka nauka społeczna (społeczna nauka Kościoła, disciplina socialis cathilica) jest konsekwencją Ewangelii: niesionej przez nią wizji człowieka i jego stosunków z innymi ludźmi, zwłaszcza w różnych dziedzinach życia wspólnotowego oraz społecznego. Wyodrębnia ją i inicjuje encyklika Rerum novarum Leona XIII z 1891 roku, a jako odrębną dyscyplinę naukową zatwierdza Quadragesimo anno Piusa XI $\mathrm{z}$ roku 1931. W dwudziestoleciu międzywojennym pojawia się w jej obrębie kilka kierunków rozwoju (w Europie i w Polsce); zyskuje ona wówczas miano socjologii chrześcijańskiej (katolickiej) ${ }^{16}$. Jako nauka szczególnie intensywnie rozwija się w Polsce w dwudziestoleciu międzywojennym, a późniejsze jej syntezy (ujęcia podręcznikowe) są tego pokłosiem ${ }^{17}$.

Humanizm katolickiej nauki społecznej, który chcemy widzieć także w pedagogice społecznej o katolickim rodowodzie, zderza się w tej próbie rekonstrukcji z uznawanym powszechnie paradygmatem humanistycznej pedagogiki społecznej nieuwzględniającym tej tradycji. Nie jest on zatem faktem oczywistym, co ma swoje przyczyny w sądach potocznych, umocowanych wkulturze masowej i popularnej, bowiem „oświeceniowy racjonalizm i naturalizm, postulujące krytycyzm wobec tradycji, w tym także religijnej, fundował zręby laickiej interpretacji

\footnotetext{
${ }^{15}$ Bogusław Śliwerski, „Chrześcijańska wizja samowychowania”. Życie Katolickie 7-8 (1986): 139-147.

${ }^{16}$ Kazimierz Święs, „Społeczna nauka Kościoła”, w: Powszechna encyklopedia filozofii, tom 9, red. Andrzej Maryniarczyk i in. (Lublin: Polskie Towarzystwo Tomasza z Akwinu 2008), 149-151.

${ }^{17}$ Historia katolicyzmu spolecznego $w$ Polsce, 1832-1939, red. Czesław Strzeszewski i in. (Warszawa: Ośrodek Dokumentacji i Studiów Społecznych 1981); Józef Majka, Filozofia społeczna (Wrocław: Wydawnictwo Wrocławskiej Księgarni Archidiecezjalnej 1982).
} 
humanizmu, która upowszechniła się w XIX wieku"18. Tym samym zacieśnił krąg myśli humanistycznej, pozostawiając poza sobą te koncepcje człowieka, które nie zredukowały go w żadnym z wymiarów i zachowały otwartość na relację ku Bogu. Myśliciele chrześcijańscy, łącząc przesłanie Objawienia ze starożytnymi analizami poznania i postępowania moralnego, ze statusem bytowym człowieka i przyjętym ideałem wychowania ${ }^{19}$, najpełniej wyrazili swój $\mathrm{h} \mathrm{umanizm} \mathrm{w}$ antropologii (neo)tomistycznej, ale też w swojej filozofii życia ${ }^{20} \mathrm{i}$ personalizmie.

W dwudziestoleciu międzywojennym mamy „wysyp” różnorodnych koncepcji nawiązujących do wyżej wskazywanych filozofii. Lecz ów ogromny ruch filozoficzny był tylko jednym ze źródeł, które zrodziły katolicką naukę społeczną; główne tkwią w samym Kościele i pracy jego hierarchów oraz w dokumentach Kościoła katolickiego. Wspomniane encykliki Rerum novarum Leona XIII (1891) oraz Quadragesimo anno (1931) Piusa XI przez całe dwudziestolecie międzywojenne stanowiły dla katolików wzór rozwiązywania tak zwanych „kwestii społecznych”. Były oficjalną wykładnią Kościoła, stając się podstawą katolickiej myśli społecznej, której główny problem zawierał się w sprawiedliwym ustroju i zasadzie sprawied li w ości s p ołec znej.

Obie encykliki znalazły w Polsce podatny grunt, bo chociaż wczasie ogłoszenia Rerum novarum kraj pozostawał pod zaborami, to dla jego kultury obecny w nich humanizm nie był nowością. W Polsce wcześniej niż w Europie uczeni i społecznicy tej miary co Paweł Włodkowic czy ksiądz Piotr Skarga SJ głosili ideę humanizmu, którego motywem przewodnim była szeroko rozumiana sprawiedliwość społeczna (odnoszona do stosunków wewnętrznych i międzynarodowych), jeszcze obca Europie Zachodniej. W „dobie encyklik” są już obecne głosy (między innymi biskupa Moguncji Wilhelma E. Kettelera czy kardynała Manninga w Anglii) w obronie robotników przed kapitalizmem, współgrające z encyklikami i promujące katolickie rozumienie humanizmu. Papież Pius XI, inicjując Akcję Katolicką w Kościele powszechnym wszystkich krajów europejskich, bronił człowieka i człowieczeństwa „niezredukowanego”, aby dać odpowiedź rosnącym w silę totalitaryzmom: komunizmowi, włoskiemu faszyzmowi czy narodowemu socjalizmowi Niemiec.

Źródłem katolickiej nauki społecznej i wyrastającej równolegle z nią pedagogiki społecznej, charakterystycznym dla Polski i trudno poddającym się formalnym ujęciom, a odgrywającym równie istotną rolę jak powyższe inspiracje, była sytuacja polityczna Polaków (odzyskanie niepodległości po półtorawiekowej niewoli) i tragiczne wyniszczenie narodu w zakresie ekonomiczno-gospodarczym, moralnym,

18 Stanisław Kowalczyk, „Humanizm”, w: Powszechna encyklopedia filozofii, t. 4, red. Andrzej Maryniarczyk i in. (Lublin: Polskie Towarzystwo Tomasza z Akwinu 2003), 655-656. Zob. też: Dominika Jagielska, Janina Kostkiewicz, Pedagogika humanizmu spolecznego Andrzeja Niesiotowskiego (Kraków: Wydawnictwo UJ 2015).

${ }^{19}$ Kowalczyk, Humanizm, 655.

${ }^{20}$ Filozofia życia uznana została przez filozofów katolickich za główną odmianę filozofii wartości. Znacząco modyfikując rozumienie życia (nie przeciwstawiając życia duchowi i uznając, że funkcje duchowe także należą do życiowych), Sawicki podjął polemikę z głównymi jej reprezentantami w Niemczech, którymi jego zdaniem byli F. Nietzsche, W. Dilthey, T. Lessing. Krytyka ta znalazła się u podstaw teoretycznych chrześcijańskiej filozofii wartości (Franciszek Sawicki, Filozofia życia [Poznań: Naczelny Instytut Akcji Katolickiej 1936]). 
kulturalnym. To źródło wiązało się z poczuciem strat spowodowanych przez zaborców i manifestowało się patriotyzmem Polaków we wszystkich sferach życia (potwierdzonym wojną obronną po napaści sowieckiej w roku 1920 i niemieckiej w 1939). To motywy patriotyczne stały u podstaw ogromnego wysiłku intelektualnego (także organizacyjnego i fizycznego), tyleż samo wzakresie spraw socjalnych, gospodarczych, co i światopoglądowych.

Wysiłek Polaków w dwudziestoleciu międzywojennym wzmacniało poczucie nakładających się zagrożeń zawartych we wpływach ideologicznych przychodzących z państw sąsiednich. Ewentualne zapanowanie komunizmu lub narodowego socjalizmu było rozumiane jako równoznaczne z utratą niepodległości, stąd szeroka fala krytyki ówczesnych totalitaryzmów wychodząca spod piór twórców katolickiej nauki społecznej ${ }^{21}$. Dlatego też w Polsce rozwijała się ona po odzyskaniu niepodległości w 1918 roku i uzyskała dodatkowe bodźce do wyjątkowo szerokiego, dynamicznego wzrostu, co dotyczy też pedagogiki społecznej.

\subsection{Filozoficzne podstawy humanistycznej pedagogiki społecznej ${ }^{22}$}

Założenia filozoficzne whumanistycznej pedagogice społecznej nie stanowią monolitu. Wiele twierdzeń - szczególnie w zakresie antropologii i aksjologii - które, choć bliskie sobie i uwzględniające chrześcijański (katolicki) kontekst, różnią się, przynależąc nie tylko do starego czy odnawianego tomizmu, ale też do intensywnie rozwijającej się u progu XX wieku filozofii życia, filozofii wartości, w końcu do personalizmu. Znajdować je możemy w pismach niżej wymienionych współtwórców humanistycznej pedagogiki społecznej (zarazem także katolickiej nauki społecznej).

Filozofem, który dał spójny wykład założeń filozoficznych tej myśli jest Franciszek Sawicki. Wskazuje on nowy ideał człowieka przyświecający humanistyce niemieckiej przełomu XIX i XX wieku, wyrażając jednocześnie krytyczny stosunek do filozofii Nietzschego, Freuda, Klagesa i innych. Zarazem przeciwstawia im ideał człowieka osadzony w filozofii i kulturze katolickiej. W stosunku do rodzącej się myśli społecznej Sawicki używa pojęcia „socjologia katolicka”, bowiem - zainspirowana Rerum novarum - powstała ona jako sprzeciw wobec marksistowskiej wizji świata (i rewolucji). Sawicki twierdzi, że najpoważniejszą z „przyczyn kryzysu kultury jest błędna antropologia, a koniecznym wymogiem czasu - antropologia nowa, uwzględniająca całą naturę ludzką i warunki życia." ${ }^{23} \mathrm{~W}$ antropologii stojącej u podstaw katolickiej myśli społecznej, gdzie człowiek uznany jest za istotę rozumną

\footnotetext{
${ }^{21}$ Janina Kostkiewicz, „Krytyka warstwy wychowawczej totalitaryzmu komunistycznego lat dwudziestych i trzydziestych XX wieku w pismach Antoniego Szymańskiego”, w: W stużbie nauki, wychowania i wartości. Szkice biograficzne olubelskim środowisku naukowym, red. Ryszard Skrzyniarz, Małgorzata Łobacz, Barbara Borowska (Lublin: Wydawnictwo „Episteme” 2015), 439-455.

${ }^{22}$ Ten i kolejne punkty niniejszego tekstu powstały na kanwie i z wykorzystaniem kilku tekstów mojego autorstwa (zob. załączoną bibliografię), w których można znaleźć szersze analizy obecnych tu zagadnień. Wprowadzone zostały też nowe teksty źródłowe i nowe interpretacje.

${ }^{23}$ Franciszek Sawicki, „Założenia filozoficzne katolickiej myśli społecznej”, w: Katolicka myśl społeczna . Pamiętnik III Studium Katolickiego w Warszawie 5-10 IX'37 (Poznań: Naczelny Instytut Akcji Katolickiej 1938), 23. Także: Kostkiewicz, Kierunki, 453.
} 
i osobową, spór dotyczy tylko p r z e j a w i a n i a s i ę godności i wolności, stosunku do świata materialnego jako kwestii ważnej w kontekście Rerum novarum i w kwestii robotniczej. Z rozumnością natury współwystępuje pierwszeństwo jej duchowego wymiaru - z nich wynika cel: jest nim rozwój ducha i jemu ostatecznie winno służyć życie (co w języku religijnym nazywa się zbawieniem duszy).

Etyka chrześcijańska - osadzona na Dekalogu - uznaje zdrowie i siłę fizyczną, rozkosz zmysłową oraz kulturę materialną jako dobra cenne, ale nie najwyższe. Bycie osobą ma konsekwencje: człowiek stanowi o swoim życiu jako mający wolną wolę i odpowiada za swe czyny, a sprawa zarówno wolności (woli), jak i odpowiedzialności dotyczy także życia narodów i dziejów ludzkości (nie można zatem uznać konieczności dziejowej w rozumieniu Hegla lub Marksa). Antropologia katolickiej nauki społecznej nie odmawia człowiekowi jego zmysłowości. Głosi, że materia stworzona przez Boga jest sama w sobie dobra, w tym zmysłowość wyrażająca się w seksualności jest także sama w sobie wartościowa i dobra. Sawicki dodaje, że ciało nie jest tylko mieszkaniem duszy - co często dominuje w nadmiernie popularyzowanych amatorskich komentarzach do religii katolickiej. Ciało należy do samej natury ludzkiej, a bez niego nie byłaby ona doskonała. Zatem asceza niszcząca ciało jest sprzeczna $\mathrm{z}$ antropologią chrześcijańską. Troska o nie oraz o materialne warunki życia jest obowiązkiem chrześcijanina. Etyka katolicka jako uniwersalna jest pełna zrozumienia dla wszystkiego, co w życiu zmysłowym piękne i niezbędne, akceptuje też dobre zjawiska kultury idące w tym kierunku.

W życiu moralnym dużą rolę odgrywa sumienie: jest ono sferą nietykalną, której nie wolno naruszać, gwałcić komukolwiek, także żadnej władzy. Wolno natomiast (i trzeba) je pouczać oraz doskonalić. Kościól, który broni autorytetu z powodu nadmiaru indywidualizmu, na etapie rozwoju nauki społecznej występuje przeciwko państwu totalnemu i broni praw osobowych oraz wolności osobistych. Nie ma w tym żadnej przekory, jest za to świadoma decyzja wynikająca z odczytania dobra człowieka, który nie może być środkiem do celu, lecz jest celem sam w sobie. Warto zauważyć, że Sawicki wypowiedział to, co w przyszłości wielokrotnie będą powtarzali personaliści: chociaż człowiek jako członek społeczeństwa jest mu podporządkowany, to jako osoba przewyższa wartością wszelkie racje społeczne (interesy i organizacje), które same w sobie nie są celem. Ich sens sprowadza się do służby człowiekowi. Z kolei społeczeństwo winno zapewnić właściwe warunki pielęgnowania duszy, której wartość przewyższa wszelkie inne dobra - z tego tylko powodu wierzący winien mieć do nich dystans. Teza o nieśmiertelności duszy wieńczy antropologię chrześcijańską ${ }^{24}$.

Chociaż wświecie dochodzi do działania złego ducha, to filozoficzna założeniowość katolickiej nauki społecznej nie niesie negatywnego nastawienia

${ }^{24}$ Sawicki, „Założenia”, 23-26. Sawicki pokazuje źródła odmiennych stanowisk przypisywanych katolicyzmowi: „filozofia indyjska, Platon, gnostycy i inni twierdzą, że ciało jest dla człowieka właściwie pierwiastkiem obcym, samo w sobie nieczyste, ciężarem duszy, że człowiek zistoty swej jest duchem, uwięzionym w świecie materialnym. Ascetyzm chrześcijański w swej dążności do uduchowienia życia okazywał często pewną skłonność do tego platonizmu. Skłonny do tego był z początku i św. Augustyn. Pogląd trzeźwej filozofii chrześcijańskiej jest inny” (tamże, 27); zob. też: Kostkiewicz, Kierunki, 453-456. 
wobec kultury świeckiej, a ewentualne zjawiska tego rodzaju nie mają w katolicyzmie źródeł. Sawicki zwraca uwagę, że uwydatnia się ono w protestanckiej teologii dialektycznej: jej etyka, czysto negatywna w stosunku do świata, jest sprzeczna z zadaniami życia w katolicyzmie. Tu bowiem uznaje się, że dobra świata mogą być zarówno przeszkodą, jak i korzystnym środkiem rozwoju duchowego (zbawienia).

Antropologia stająca u podstaw katolickiej nauki społecznej, a w następstwie tego u podstaw humanistycznej pedagogiki społecznej, stanowi uzasadnienie dla konkretnego porządku społecznego. Zarówno z nią, jak i z teologią katolicką łączy się aksjologia, którą Sawicki uznaje za trzeci filozoficzny wymiar podstawowy dla myśli społecznej.

Myśl społeczna, a zarazem humanistyczna pedagogika społeczna lat 20. i 30. XX wieku, posiada swoje podstawy filozoficzne nie tylko w pracach Franciszka Sawickiego, ale także Andrzeja Niesiołowskiego ${ }^{25}$, Konstantego Michalskiego ${ }^{26}$, Jacka Woronieckiego, ${ }^{27}$ Józefa Pastuszki ${ }^{28}$, Kazimierza Kowalskiego ${ }^{29}$ i innych. W związku z tym, że celem niniejszego szkicu nie jest wyczerpujące zgłębianie kwestii podstaw filozoficznych, dość przypomnieć, że „tomizm znacznie różni się w swoich założeniach ontologicznych i epistemologicznych od personalizmu. Wyciąga również odmienne wnioski odnośnie do koncepcji wychowania" ${ }^{30}$. Warto też podkreślić, że w praktycznej działalności społeczno-oświatowej bardziej widoczne stają się elementy wspólne niesione przez wymienione filozofie: katolickie podstawy teologiczne (przykład ich filozoficzno-teologicznego ujęcia zawiera między innymi rozprawa Marka Rembierza $^{31}$ ), uznanie niezbędności integralności wychowania, ważność kwestii społecznych oraz społecznego zakorzenienia człowieka.

\section{Twórcy humanistycznej pedagogiki społecznej}

Rekonstrukcja humanistycznej pedagogiki społecznej winna uwzględniać grono twórców, których dorobek - ze względu na poszukiwanie jej w obszarze katolickiej nauki społecznej oraz uznanie jej inspirującej roli - zawiera zarówno koncepcje

\footnotetext{
${ }^{25}$ Andrzej Niesiołowski, Personalizm i jego perspektywy (Warszawa: odbitka z Verbum 3 (1938); tegoż, „Personalizm i kolektywizm”. Kultura i Wychowanie 1 (1937): 16-34.

${ }^{26}$ Konstanty Michalski, Nieznanemu Bogu (Kraków: Koło Studiów Katolickich i Naukowy Instytut Katolicki 1936).

${ }^{27}$ Jacek Woroniecki, Wychowanie człowieka. Pisma wybrane (Kraków: Wydawnictwo „Znak” 1961).

28 Józef Pastuszka, „Obiektywizm u podstaw myśli katolickiej”. Prąd 17 (1929): 123-140; tegoż, „Współczesne prądy filozoficzne”. Kultura i Wychowanie 3 (1938): 202-217.

${ }^{29}$ Kazimierz Kowalski, „Rola podstawowych praw filozoficznych w odrodzeniu osobistem i społecznem”. Ateneum Kaptańskie 20 (1927): 451-469.

${ }^{30}$ Jarosław Horowski, „Tomistyczna myśl pedagogiczna w Polsce wobec idei personalizmu”. Kwartalnik Pedagogiczny 2 (2011): 29-60.

${ }^{31}$ Marek Rembierz, ,Sensus catholicus: uniwersalizm, obiektywizm, realizm. Myśl filozoficzno-teologiczna i działalność pedagogiczno-duszpasterska Jacka Woronieckiego OP w rozprawach i wspomnieniach Stefana Swieżawskiego", w: Człowiek - moralność - wychowanie. Życie i myśl Jacka Woronieckiego OP, red. Jerzy Gałkowski, Maurycy L. Niedziela (Lublin: Towarzystwo Naukowe KUL 2000).
} 
wychowania (pedagogiki społecznej), jak i prace ją współtworzące. Wszyscy niżej wymienieni twórcy humanistycznej pedagogiki społecznej są zarazem wskazywani jako przedstawiciele katolickiej nauki społecznej ${ }^{32}$.

Aleksander Wóycicki (1878-1954) - jego koncepcja wychowania społecznego (konkretnie: wychowanie do sprawiedliwości społecznej) w sposób wybitnie klarowny odsłania się jako konsekwencja i obszar katolickiej nauki społecznej ${ }^{33}$. Już na wstępie warto stwierdzić, że Wóycicki w pracy naukowej oraz działalności społecznej skierowanej do młodzieży i dorosłych posługuje się spójną koncepcją humanistycznej pedagogiki społecznej. Świadom istoty, a także zadań katolickiego wychowania społecznego, tworzy koncepcję adekwatną do ówczesnej sytuacji społecznej, ekonomicznej i kulturowej Polski.

Proponuje ideał wychowania społecznego oraz aspekty rzeczywistości, w której ono zachodzi, zakreślając tym samym obszar i zakres przedmiotu pedagogiki społecznej. Nowatorsko i kompetentnie prowadzi swoje badania; jako znawca teorii społecznych, filozoficznych i ekonomicznych dokonuje ich krytyki, świadom zagrożeń, które niosą. Formułuje definicję wychowania odsłaniającą jego socjologiczny punkt widzenia: „wychowanie jest to przygotowanie młodego pokolenia do życia w społeczeństwie. Ze swej natury wychowanie jest społeczne; a po [(...) stwierdzeniu - JK] niesprawiedliwości w ustroju dzisiejszym, dochodzimy do przekonania, że wychowanie społeczne, wybitnie społeczne, dążące do zupełnego jej zniesienia, jest niezbędne." ${ }^{34}$ Swoje pedagogiczne poglądy zawiera między innymi w pracach Wychowanie społeczeństwa (1938), Rola wychowania wnaprawie niesprawiedliwości spotecznej (1936), Praca spoleczna w parafii. Szkic historyczno-spoteczny (1937), Podstawy wychowania moralnego (1934), Wychowanie i ustrój spoteczny (1936) oraz innych.

Andrzej Niesiołowski (1899-1945) - humanistyczna pedagogika społeczna to tylko część ogromnego dorobku tego pedagoga, filozofa i socjologa, który został określony szerzej jako pedagogika humanizmu społecznego ${ }^{35}$. Mieści ona w sobie dwa podstawowe wymiary: zobowiązanie do rozwoju osobowego (głęboko zakorzenione $w$ kulturze chrześcijańskiej oraz rozwiązaniach personalistycznych) oraz wymóg zaangażowania w przebudowę struktur życia społecznego (wychowanie w społeczeństwie i dla społeczeństwa). Kultura społeczna i naród stanowią fundamenty wychowania. Rola oświaty, kondycja rodziny oraz własna praca samokształceniowa stanowią ramy społecznego wychowania człowieka. Główne prace składające się na humanistyczną pedagogikę społeczną Niesiołowskiego to: Metody

\footnotetext{
${ }^{32}$ Zob. Strzeszewski, Katolicka, 7-730.

${ }^{33}$ Zob. Kostkiewicz, Kierunki, 429-440.

${ }^{34}$ Aleksander Wóycicki, „Rola wychowania w naprawie niesprawiedliwości społecznej”, w: Katolicka myśl wychowawcza. Pamiętnik II Studium Katolickiego w Wilnie w d. 28. VIII - 1. IX. 1936 r. (Poznań: Naczelny Instytut Akcji Katolickiej 1937), 430. Przez naprawę niesprawiedliwości społecznej Wóycicki rozumie „wprowadzenie ustroju sprawiedliwego, czyli jego «odnowienie i dostosowanie do normy prawa Ewangelii»" (tamże, 426).

${ }^{35}$ O pedagogice Niesiołowskiego piszę w: Kostkiewicz, Kierunki, 429-440; poświęcona jest jej też cała monografia: Jagielska, Kostkiewicz, Pedagogika.
} 
realizacji wychowania społecznego (1936), Sprawa koordynacji katolickiego ruchu społecznego (cz. 1 i 2; 1929), Wychowanie społeczne (1936), Zagadnienie konsumenta kulturalnego i polityki kulturalnej (1936), Koła oświatowo-wychowawcze. Zadania - teoria - wskazania praktyczne (1939).

J a c ek Woroniecki (1878-1949) - w jego twórczości wychowanie społeczne nie dominuje, ale jest istotnym elementem wychowania integralnego. Dostrzega on brak w języku polskim terminologii stosownej do oddania istoty cnoty „chęci ku dobru pospolitemu” 36 i wprowadza pojęcie cnoty społecznej i cnoty uspołecznienia $^{37}$. Z nadzieją patrzy na zjawisko negowania czysto indywidualistycznego pojmowania sprawiedliwości, a potrzebę powrotu do wychowania społecznego widzi w negatywnych skutkach indywidualizmu. Uzasadnia to tym, że whistorycznym rozwoju etyka społeczna nie była działem etyki ogólnej, ale obszarem, na którym rozpatrywano etykę indywidualną, co w przeszłości prowadziło do uznawania jej za część etyki społecznej ${ }^{38}$.

Pierwszy etap wychowania społecznego odbywa się w rodzinie, kolejnym jest szkoła, która silniej niż rodzina akcentować musi ową konieczność liczenia się z dobrem wspólnym dla zapewnienia ładu, porządku i spokoju pracy ${ }^{39}$. Dalej tę rolę pełni Kościół (który wówczas wychowywał nie tylko indywidualnie, ale i społecznie), winno się mieć na względzie nieustanne branie pod uwagę dobra społeczności. Dlatego Woroniecki proponuje wzmacnianie społeczno-wychowawczego charakteru nabożeństw, podkreśla znaczącą rolę aktywności obywatelskiej, począwszy od działań w samorządzie, a spółdzielczość uznaje za szkołę wychowania społecznego: „kooperatywy i związki spółdzielcze mają pod względem wychowania do pracy społecznej duże znaczenie"40. Cała twórczość Woronieckiego jest przesycona istotnym wychowawczo nachyleniem społecznym, szczególnie prace: Wychowanie społeczne i praca społeczna (1921), Katolicka etyka wychowawcza (1925 i nast.), Społeczeństwo a wychowanie (1916), Umiejętność rządzenia i rozkazywania (1947) oraz inne.

S t e fa n W y z z ń s ki (1901-1981) - twórczość późniejszego Kardynała i Prymasa Polski z okresu dwudziestolecia międzywojennego jest najmniej znana. Wyróżnia się ona na tle ruchu intelektualnego zmierzającego ku naprawie sfery społecznej i obywatelskiej. Dla humanistycznej pedagogiki społecznej istotne są między innymi prace: Zasięg i charakter zainteresowań katolickiej myśli społecznej (1937), seria artykułów Przemiany moralno-religijne pod wptywem bezrobocia (1937), Posady dla ojców rodzin (1933), Problemy społeczno-moralne wsi w „Pamiętnikach Chłopów” (1938), Wymowa procesów chłopskich (1933), Społeczeństwo i prasa a wychowanie młodzieży (1933), Stosunek naszej mtodzieży

\footnotetext{
${ }^{36}$ Jacek Woroniecki, Wychowanie spoleczne i praca spoleczna (Warszawa: „Biblioteka Prądu” 1921), 12-13.

${ }^{37}$ Tamże, 14, 17-19.

${ }^{38}$ Tegoż, Katolicka etyka wychowawcza, t. 1 (Lublin: Redakcja Wydawnictw KUL 1986), 28-29.

${ }^{39}$ Tegoż, „Zdolność wychowawcza szkoły publicznej i jej granice”. Miesięcznik Katechetyczny i Wychowawczy 5-7 (1924).

${ }^{40}$ Tegoż, Wychowanie, 32.
} 
akademickiej do Kościoła (1927), Katolicy wtoscy ipolscy wobec swych uniwersytetów katolickich (1932), Warszawski Kongres do walki z handlem żywym towarem (1931). Prace te na gruncie pedagogiki mogą być podstawą zrekonstruowania koncepcji wychowawczej o konkretnym ideale, celach, treściach i metodach oddziaływania społecznego. Odsłaniają także nie zawsze dotąd uznawany przedmiot oraz teren badań pedagogiki społecznej.

Stanisław Adamski (1875-1967) - społeczno-pedagogiczna działalność biskupa Adamskiego odbywała się w duchu encyklik papieskich i zaznaczyła się najbardziej we współtworzonym przez niego programie Akcji Katolickiej, za której działalność był odpowiedzialny (opracował Statut, podstawy organizacyjne i zasady pracy na różnych poziomach jej funkcjonowania). Znalazła ona wyraz w pracach: Podstawy pracy Stowarzyszeń Akcji Katolickiej (1937), Parafialna Akcja Katolicka (1938), Szkoła wyznaniowa czy mieszana (1922), Szkoła wedle nauki Kościoła i uchwat Synodu (1939). Oddzielenie szkolnictwa wszelkich szczebli od Kościoła uznawał za szkodliwe dla przyszłej kondycji moralnej człowieka, widząc w oderwaniu od religii praktyczne wcielanie relatywizmu moralnego i sceptycyzmu. Problemem istotnym w całej pracy biskupa Adamskiego była szkoła wyznaniowa, której był gorącym zwolennikiem (podkreślając, że charakteryzuje się ona całościowym wychowaniem w duchu jednej religii, a nauczyciele są tego samego wyznania co uczniowie). Praca społeczno-pedagogiczna biskupa Adamskiego doczekała się szczegółowych opracowann ${ }^{41}$.

Stef an Abt (1898-1942) - ksiądz, doktor. Po studiach w Instytucie Katolickim w Lyonie pracował jako redaktor Roczników Zwiq̨zu Akademickich Kót Misyjnych w Polsce, co wiązało się z predyspozycjami do pracy społecznej. Dla obszaru humanistycznej pedagogiki społecznej najbardziej znaczące są zagadnienia związane ze stowarzyszeniami młodzieży katolickiej. W pracach o wychowaniu w stowarzyszeniach nie tracił z oczu zagadnienia ważności celów wyznaczanych wychowaniu i stojącej za nimi polityki oświatowej państwa. Wśród kilkudziesięciu pozostawionych prac liczne współtworzą pedagogikę społeczną, dotąd jednak nie zostały dla niej odkryte. Przykładami są: Pius XI Papież o stowarzyszeniach mtodzieży katolickiej (1939), O celu wychowania ipolityce szkolnej (1936), Wychowanie religijne na tle ruchu pedagogicznego (1932).

Ludwika Dobrzyńska-Rybicka (1868-1958) - doktor, wykładowca Uniwersytetu Poznańskiego, związana z jego środowiskiem socjologicznym. Uczestniczyła w życiu naukowym środowisk pedagogicznych: I Katolickim Studium o Rodzinie w Poznaniu (1935), II Studium Katolickim w Wilnie (1936). Interesowały ją: Czynniki wychowania moralnego w pracy zbiorowej (1934), Zadania świata kobiecego wobec kryzysu rodziny (1936), Wychowanie państwowe (1937), Wyzwolenie człowieka jako zagadnienie wychowawcze (1935) i inne. Współpraca

\footnotetext{
${ }^{41}$ Np. Z życia i publicznej działalności biskupa Stanistawa Adamskiego, przyg. do druku, wstęp i przyp. Andrzej Gulczyński (Poznań: Księgarnia św. Wojciecha 2000).
} 
z Florianem Znanieckim, ewentualnie z obecnym w tym czasie w UP Andrzejem Niesiołowskim, nie jest bliżej zbadana.

M i c h a ł S o p oć k o (1888-1975) - ksiądz, profesor. Habilitację uzyskał w zakresie historii wychowania i problematyki ogólnopedagogicznej, natomiast w pracy społecznej podjął się przede wszystkim walki z alkoholizmem poprzez wykłady, odczyty oraz pracę w parafii. Pisał o alkoholizmie wśród młodzieży szkolnej, podejmował zagadnienie swoistej profilaktyki polegającej na wychowaniu zaszczepiającym wyższe wartości i zainteresowania korzystne wychowawczo. Spośród innych problemów o charakterze społecznym pojawiają się wybrane kwestie wychowania w rodzinie: tu podejmował złożoną problematykę autorytetu w kontekście wolności i praw dziecka. Pisał także o obowiązkach społecznych jako o dziedzinie, do której trzeba człowieka wychować - dla dobra jego samego oraz dla narodu i państwa jako dobra wszystkich w nim żyjących. Był zaangażowany w społeczną realizację dzieła Miłosierdzia Bożego zainicjowanego przez siostrę Faustynę Kowalską. Na uwagę pedagoga społecznego zasługują: Alkoholizm a młodzież szkolna (1929), O obowiązkach społecznych (1931), Nauka przedślubna (1948), Obowiązki rodziców chrzestnych (1936), Autorytet $w$ rodzinie a wolność dziecka (1939).

A n t o n i S z y m án s ki (1881-1942) - ksiądz, profesor, rektor KUL, jeden z głównych twórców katolickiej nauki społecznej. Jego pisma obejmują pewne aspekty z obszaru wychowania społeczno-politycznego, z którym wiąże się też podejmowana problematyka rozwodów (Społeczne znaczenie rozwodów, 1931), moralnej strony aborcji i wychowania ku kulturze życia (Zasadniczy problemat etyki ptciowej, 1930). Nieformalną edukację wybitnie polityczną posiadały teksty Szymańskiego o ideologiach totalitarnych kreujących „postępowe” wówczas wizje świata ${ }^{42}$.

I g n a c C C z u a (1891-1963) - uczony i polityk, poruszał szeroko rozumiane zagadnienia wychowania społecznego między innymi w takich pracach jak: Wolność narodu w państwie (1939), Filozoficzne punkty styczne zachodu i bolszewizmu (1930), Polityka ludnościowa III Rzeszy (1939). Z perspektywy humanistycznej pedagogiki społecznej wjego twórczości ważne są kwestie bytu podmiotowego, wolności człowieka i jej przejawów oraz praca pedagogiczna w KUL jako rektora i dziekana. Może ona odegrać istotną rolę w rekonstrukcji wychowania politycznego w dwudziestoleciu międzywojennym.

J a n Piwowarczyk (1889-1959) - ksiądz prałat, doktor, tomista, dziennikarz, publicysta, osobowość nieprzeciętna, postać barwna i znana ze swej aktywności społecznej głównie w Krakowie. Związany był przez pewien czas z Uniwersytetem Jagiellońskim. Z poruczenia kardynała Sapiehy twórca i założyciel „Tygodnika Powszechnego” oraz Wydawnictwa „Znak” (z którego szybko odszedł, zdominowany przez innych). Autor prac: Współczesne kierunki społeczne (1927), Charakter i jego istota (1938), Przyszłość myśli katolicko-spolecznej i warunki jej

\footnotetext{
${ }^{42}$ Janina Kostkiewicz, „Krytyka warstwy”, 439-455.
} 
realizacji w Polsce (1938), Międzynarodówka Chrześcijańskich Związków Zawodowych (1931), Oddziaływanie dzisiejszych stosunków w świecie pracy na życie moralne i religijne robotnika (1927) - w sumie kilkunastu książek i broszur oraz niezliczonej liczby artykułów, których drobny wybór opublikowano w $1985 \mathrm{roku}^{43}$. Po działalności społecznej wywołującej ogromny rozgłos szybko zapomniany, także w środowisku katolickim.

Co upoważnia do zaliczenia księdza Jana Piwowarczyka do grona pedagogów społecznych? Mimo roli wykładowcy w UJ i obronionego tu doktoratu, Piwowarczyk nie wszedł $w$ rolę uczonego-badacza. Wręcz intencjonalnie głównej swojej pracy nadał rolę popularyzatorską: miała służyć edukacji społecznej, politycznej i ekonomicznej, być materiałem orientacyjnym dla organizacji chrześcijańsko-społecznych, nieść wiedzę polityczną, zwłaszcza o ideologiach ${ }^{44}$ niezbędną (ze względu na treść Rerum novarum) wszystkim katolikom bez względu na wiek i zawód. Piwowarczyk prace publikował z wyraźną intencją edukacyjną, znajdując dowody ,jak źle jest z naszą wiedzą społeczno-ekonomiczną i jakie zamieszanie pojęć panuje w tej dziedzinie" ${ }^{\prime 5}$. Pisząc o kierunkach społecznych: liberalizmie, socjalizmie i kierunku chrześcijańskim, wyjaśniał pojęcia i dokonywał krytyki. Wyrażał przy tym troskę o stan rozwoju kierunku chrześcijańskiego, w którego „ludowych” odmianach i ich programach pracy społecznej panuje pomieszanie pojęć różnych kierunków (co oznacza, że zjawisko „hybrydy ideologii” społecznej, ekonomicznej, edukacyjnej było już wówczas problemem, ale i pewnie „metodą" przemycania haseł ideologii będących w ofensywie).

Piwowarczyka interesowało sprawstwo wychowawcze. W tej kwestii, jego zdaniem, to etyka chrześcijańska „stanowi największą siłę wychowawczą. Nic lepszego w tej dziedzinie ludzkość nie wynalazła. I znane są dobrze wyroki takich myślicieli jak Foerster [(...) stwierdzający - JK], że «egoizm ludzki może być pokonanym tylko przez chrześcijaństwo» (Foerster)"46.

Ksiądz Piwowarczyk poprzez swoją aktywność naukową i społeczną praktycznie współuczestniczył w budowaniu podstaw wychowania społecznego. Znamienny był jego udział w III Katolickim Studium w Warszawie (1937), gdzie zabierał głos w sprawie przyszłości i warunków realizacji założeń społecznej myśli katolickiej w Polsce ${ }^{47}$. Był reprezentantem katolickiej nauki społecznej świadomym roli i potrzeby wychowania. Uważany przede wszystkim za propagatora społecznego

${ }^{43}$ Jan Piwowarczyk, Wobec nowego czasu (z publicystyki 1945-1950), wybór i układ Jerzy Kołątaj, słowo wstępne Jerzy Turowicz (Kraków: Społeczny Instytut Wydawniczy „Znak” 1985), 441.

${ }^{44}$ Tegoż, Wspótczesne kierunki społeczne (Kraków: Nakładem Związku Katolickich Stowarzyszeń Diecezji Krakowskiej 1927), 2.

${ }^{45}$ Tamże.

${ }^{46}$ Tamże.

${ }^{47}$ Jan Piwowarczyk, „Przyszłość myśli katolicko-społecznej i warunki jej realizacji w Polsce”, w: Katolicka myśl społeczna, 173-192. 
nauczania Kościoła, poprzez swoje prace tworzył pogranicze humanistycznej pedagogiki społecznej, szczególnie wdziedzinie wychowania obywatelskiego i politycznego.

M a ri a n P i r oży ń s ki (1899-1964) - ksiądz, redemptorysta, doktor, zaangażowany w pracę społeczną i bieżące problemy codziennego życia politycznego. Walczył z arogancją władzy w obronie wiernych Kościoła katolickiego zarówno przed, jak i po II wojnie światowej. Był publicystą, gorącym zwolennikiem wprowadzania w życie nowoczesnej katolickiej nauki społecznej ${ }^{48}$. Swoją pracę społecznika zaangażowanego w realizację wartości katolickich, narodowych i społecznych rozpoczął w latach trzydziestych: w nurt społecznego nauczania Kościoła weszły nie tylko jego publikacje, ale też aktywna postawa duchownego walczącego o społeczną zgodność nauczania Kościoła i praktyki życia. Do wartościowszych prac można zaliczyć: Wynurzenia bezrobotnego (1938) oddające dramat człowieka dotkniętego tym zjawiskiem. O naprawie życia społecznego i powinnościach aktywnego udziału w nim duchowieństwa pisał natomiast w publikacjach Udzial kaplana w reformie spolecznej (1939) oraz Wychowawca młodzieży (1939).

Katolicka myśl przywołanych twórców poświęcona problematyce człowieka i społeczeństwa przesycona jest pedagogiczną ideą scalającą kategorie: osoba rodzina - naród. Stanowi ona oś moralną organizującą życie i wychowanie według Ewangelii. Wskazani wyżej autorzy, podejmując je (mimo iż czynili to często w sposób wybiórczy), przyczyniali się do ich obecności w ówczesnej przestrzeni publicznej i wychowawczej. Wymienione nazwiska nie wyczerpują jednak grona przedstawicieli humanistycznej pedagogiki społecznej (i katolickiej nauki społecznej). Aspektów wychowania społecznego dotykają prace Ludwika Górskiego ${ }^{49}$, Karola Górskiego ${ }^{50}$, czy choćby Feliksa Konecznego i innych. Ostatni z nich niezwykle mocno podkreślał, że eliminacja miłość z życia społecznego rodzi niesprawiedliwość - miłość jest wprawdzie pierwsza, ale nie zaistnieje ona tam, gdzie nie ma sprawiedliwości. Dodać koniecznie trzeba, że rozwój myśli społecznej i wychowania społecznego w II Rzeczypospolitej miał swój klimat patriotyczno-religijny, który nadawali mu kardynałowie: Aleksander Kakowski, książę Adam Sapieha, August Hlond. W ich postawach godność narodu znajdowała swe potwierdzenie.

${ }^{48}$ Jego działalność pedagogiczna stała się przedmiotem monografii Kazimierza Pelczarskiego (tegoż, Działalność wychowawcza o. Mariana Pirożyńskiego 1899-1964 [Lublin : Towarzystwo Naukowe Katolickiego Uniwersytetu Lubelskiego Jana Pawła II 2006]).

${ }^{49}$ Ludwik Górski, „Katolicyzm społeczny”. Ateneum Kapłańskie 16 (1919-1925): 33-48.

${ }^{50}$ Karol Górski, „Sprawiedliwość i miłość w życiu społecznem”. Prąd 17 (1929): 187. 


\section{Dziedziny wychowania humanistycznej pedagogiki społecznej}

W wyłonieniu poddziedzin (bowiem samo wychowanie społeczne jest jedną z głównych dziedzin) warto posłużyć się jakimś wzorcem. Sięgając do interpretacji Maritaina widzimy, że w obrębie dziedziny wychowania społecznego wskazuje on:

1) wychowanie społeczne w sensie ścisłym (uwzględniające wnoszenie w życie społeczne przez każdego człowieka jego bogactwa wewnętrznego, podnoszące kwestie szacunku do bliźniego, współpracy, odpowiedzialności);

2) wychowanie obywatelskie (kształtowanie cnót obywatelskich: współdziałania dla dobra wspólnego, podporządkowania dobra własnego dobru wspólnemu, posłuszeństwa autorytetowi);

3) wychowanie polityczne (tworzenie oraz reformowanie urządzeń życia społecznego i politycznego; tworzenie instytucji oraz administrowanie nimi; partycypacja w życiu partii politycznych, a także stowarzyszeń) $)^{51}$.

Przyjmując powyższą klasyfikację, staję jednocześnie wobec natłoku dominujących problemów, które kwalifikują się do obszaru humanistycznej pedagogiki społecznej, takich jak:

a) edukacja w obrębie praw podmiotowych osoby, rodziny i narodu;

b) edukacja kulturalna młodzieży i dorosłych, w tym religijna (wychowanie religijne), której nadaje się nie tylko sens osobowy, ale i ogólnonarodowy oraz wręcz cywilizacyjny;

c) edukacja ekonomiczno-gospodarcza dorosłych i młodzieży (z przygotowaniem do zawodu);

d) edukacja pedagogiczna dorosłych skierowana na jakość własnego życia w różnych sferach, w tym jakość opieki i wychowania dziecka w rodzinie oraz rola społeczno-kulturowa rodziny;

e) poradnictwo rodzinne, zawodowe, opiekuńcze, zdrowotne, zarówno o charakterze społecznym, jak i państwowym (na przykład Poradnie Matki i Dziecka, Poradnie Małżeńskie).

\subsection{Wychowanie społeczne w sensie ścisłym}

W tej dziedzinie wychowanie rozpoczyna się od możliwości wniesienia przez każdego człowieka w życie społeczne swego bogactwa wewnętrznego. Wskazuje się na tkwiące w człowieku potrzeby życia społecznego i takiegoż wychowania. Jacek Woroniecki uznaje za ważne istnienie w charakterze moralnym człowieka czynników uzdalniających go do czynności społecznych i kierujących go w stronę społeczności. Społeczne usposobienie ludzkiej woli jest dla Woronieckiego „stałym nastrojem”, dzięki któremu człowiek liczy się z wymaganiami dobra ogólnego i stara się ten ład umocnić.

${ }^{51}$ Tomasz Ożóg, „J. Maritaina koncepcja wychowania człowieka”. Roczniki Nauk Spolecznych KUL 2 (1993): 16. Poddziedziny składające się na dziedzinę wychowania społecznego będą tu dla uproszczenia skrótowo określane jako „dziedzina”. 
Program dla demokratycznego wychowania społeczeństwa może sprawić, „że pełne prawa, udzielone najszerszym warstwom ludu, nie będą czymś iluzorycznym, nierealnym [...]. Bez tego wychowania, rządy demokratyczne będą czczym frazesem, a masami rządzić będą kliki agitatorów, co do których możemy być pewni, że z obawy przed utratą wpływów będą się z całej siły przeciwstawiali wszelkim zabiegom w kierunku społecznego wychowania ludu." 52

Akcentując powyższe uzasadnienie potrzeby wychowania społecznego, wskazywano także na niesprzyjające mu czynniki zewnętrzne, jakimi były między innymi ideologie totalitarne. W wielu pracach wskazanych twórców znajdujemy genezę tych ideologii, które zagrażały cywilizacji chrześcijańskiej, oraz ich krytykę. Dotyczy to nie tylko bolszewizmu i niemieckiego narodowego socjalizmu; za niesłużącą wychowaniu społecznemu, bo sprzeczną z naturą człowieka, uznawano też ideologię liberalną „opowiadającą się za koncepcją człowieka-egoisty, kierującego się w swoich działaniach ekonomicznych i społecznych motywem zysku i przyjemności" ${ }^{3}$; obok Woronieckiego podobne oceny głosili K. Michalski i A. Niesiołowski. Woroniecki wybuch indywidualizmu w XVI wieku uznawał za główne źródło i przyczynę oderwania się wychowania społecznego od wychowania w ogóle. W ramach przeciwdziałania temu proponował wprowadzenie do programów szkolnych nauki o obowiązkach obywatelskich ${ }^{54}$. Istniały także inne projekty wdrożenia problematyki wychowania obywatelskiego jako przedmiotu edukacji młodzieży ${ }^{55}$.

Wychowanie społeczne w sensie ścisłym obejmuje budowanie chrześcijańskiego społeczeństwa sprawiedliwości społecznej. Koncepcję wychowania do sprawiedliwości społecznej znajdujemy u księdza Aleksandra Wóycickiego. Wskazuje on zadania wychowania społecznego, jakie należałoby zrealizować dla osiągnięcia tego celu.

«Najogólniejsze ich ujęcie jest następujące: stworzyć trzeba nowy typ wychowania społecznego poprzez spowodowanie poznania przez społeczeństwo (poczynając od uczniów, kończąc na robotnikach) nowych idei przewodnich i nowych poglądów na życie zbiorowe (głoszonych przez katolicką naukę społeczną); następnie trzeba wprowadzić je do umysłów, sumień i serc ludzkich w wychowaniu rodzinnym, szkolnym i pozaszkolnym; na jego bazie trzeba gruntownie przekształcać obyczaje życia społecznego (politycznego, gospodarczego, kulturalnego), jego instytucje i sam ustrój. ${ }^{56}$ Rozumie więc Wóycicki wychowanie społeczne bardzo szeroko - w jakimś sensie realizuje się ono przez samo życie społeczne, a jego efekty

\footnotetext{
${ }^{52}$ Woroniecki, Wychowanie spoleczne, 30.

${ }^{53}$ Ryszard Polak, „Woroniecki Jacek Adam”, w: Powszechna encyklopedia filozofii, tom 9, red. Andrzej Maryniarczyk i in. (Lublin: Polskie Towarzystwo Tomasza z Akwinu, 2008), 845.

${ }^{54}$ Woroniecki, Wychowanie spoleczne, 6-7, 18.

${ }^{55}$ Kazimierz Krotoski, „Kultura i lojalność obywatelska jako przedmiot wychowania młodzieży”. Przegląd Powszechny 143 (1919): 53-59 oraz 144 (1919): 151-161.

${ }^{56}$ Wóycicki, „Rola”, 432.
} 
nie są efektami mierzalnymi na terenie szkoły, lecz mierzone są zmianami w życiu społecznym. Odnosząc się do tych zadań głębiej, dodać należy, że:

1. Ideał wychowania społecznego w twórczości Aleksandra Wóycickiego sprowadzony jest do ideału sprawiedliwości społecznej ${ }^{57}$. Mimo, że tak sformułowany ideał wychowania nie sprowadza się u Wóycickiego do ideału wychowanka (w postaci na przykład ideału obywatela), nie oznacza braku obecności perspektywy personalistycznej. Ideałem wychowania jest ideał społeczeństwa - to ono wyznacza zaistnienie jakości pożądanych" ludzkiego życia. Jeżeli w obrębie realizacji tego ideału należycie damy poznać młodzieży katolicką naukę społeczną i jej stanowisko w sprawach gospodarczych, rodzinnych, zawodowych, obywatelskich i międzynarodowych - dane te wyznaczą ,jakości” rozwoju osobowego.

2. W ramach tegoż wychowania społecznego człowiek (jako osoba, jako jednostka) nie jest zmarginalizowany, ani tym bardziej zinstrumentalizowany. We własnej koncepcji wychowania, Wóycicki zaleca kształcić „«duszę» to znaczy sumienie [dba o rozwój człowieka, aż po najwyższą - duchową ('światopoglądową) warstwę wychowania - JK], a więc świadomość swej odpowiedzialności osobistej tudzież świadomość odpowiedzialności rodzinnej, zawodowej, obywatelskiej i międzynarodowej"58 Obok wpajania świadomości własnej odpowiedzialności każdego ucznia, wymaga od szkoły uwrażliwienia na problemy społeczne, specyficzne dla różnych grup zawodowych: kupców, inżynierów, rolników, pracowników najemnych.

3. Naukę moralności (ewangelicznej) w ramach wychowania dostosować należy do aktualnych czasów - ich trudności, wymogów, zjawisk groźnych - trzeba uświadamiać młodzież na jakim polu przychodzi jej działać (strajk, lokaut, manifestacja, krzywda, egoizm, wyzysk - tych zjawisk nie należy ukrywać). Wóycicki podkreśla, że nie chodzi mu o agitację wśród młodzieży szkolnej, o szerzenie demagogicznych haseł, lecz o to, by: „mówić prawdę, wykazywać rzeczywistość, wdrażać do duszy poczucie sprawiedliwości." 59

4. Kolejnym z zadań jest respekt dla kwestii uczuć w wychowaniu społecznym miłość braterska winna być tam na pierwszym miejscu, pisze Wóycicki. Obok niej winny

57 Treść tego ideału niesie katolicka nauka społeczna, którą między innymi przeciwstawić należy „naturalizmowi społecznemu nie jako tezę czysto spekulatywną lub jako chimeryczny ideał, ale jako ideał konkretny, jako typ praktyczny, jako cel, do którego dążý ma społeczeństwo” (Wóycicki, „Rola”, 433). Za katechizm społeczny Kościoła (zawierający wykład o sprawiedliwości społecznej) uznaje Wóycicki encyklikę Quadragesimo Anno, o której pisze: „nie ma ona nic z komunistycznej utopii Platona, Morusa, Marksa czy Lenina, nic z czczego racjonalizmu socjologii pozytywistycznej, ale bierze człowieka i społeczeństwo zupełnie realnie - w myśli filozofii Arystotelesowskiej o jego «zoon politikon» - czyli o osobie ludzkiej jako stworzeniu społecznym; opiera się na ściśle sprecyzowanym pojęciu porządku chrześcijańskiego i ogólnego dobra, po mistrzowsku wyłożonym w wiekopomnych dziełach św. Tomasza” (tamże, 435-436).

${ }^{58}$ Wóycicki, „Rola”, 437. Aleksander Wóycicki pisząc historię funkcji społecznych pełnionych przez parafię, pokazuje ją jako ośrodek życia obywatelskiego i społecznego oraz mającego tam miejsce takiegoż wychowania (Aleksander Wóycicki, Praca społeczna w parafii. Szkic historyczno - spoteczny (Poznań: NIAK, 1937).

${ }^{59}$ Wóycicki, „Rola”, 438. 
zaistnieć uczucia ofiary dla dobra społecznego, dla lepszego porządku społecznego. Żaden ruch społeczny, masowy (Wóycicki myśli tu o realizację ideału wychowania społecznego) nie zaistnieje bez odwoływania się do uczuć, więcej, do działania „trzeba mistyki” - twierdzi Wóycicki. ${ }^{60}$

W obrębie powyższych zadań odsłania się humanizm tej koncepcji. Aleksander Wóycicki porusza jednak jeszcze wiele innych kwestii, którymi z jednej (metodologicznej) strony zarysowuje zakres jej przedmiotu zainteresowań (badań), z drugiej - podstaw filozoficzno-pedagogicznych, poprzez które doprecyzowuje treść wskazanego ideału wychowania. W propozycji wychowania społecznego umieszcza określone modele społeczeństwa i człowieczeństwa - skorelowane ze sobą, świadomie wybrane elementy tego wychowania wyprowadzone są z chrześcijaństwa.

Prace Wóycickiego wychodziły naprzeciw wielu społecznikom pracującym nad podniesieniem z nędzy warstw najbardziej krzywdzonych; ten rodzaj działalności prowadzony na Pomorzu przez księdza Henryka Szumana opisuje Wiesław Theiss ${ }^{61}$.

W ramach wychowania społecznego (w sensie ścisłym) mieści się projekt księdza Piwowarczyka dotyczący utworzenia inspirowanej religijnie oświatowo-kulturalnej organizacji robotników. Posiadał on kilka cech istotnych z perspektywy Polski pozaborowej: jednolita organizacja w całym kraju (co miało znaczenie dla scalania obszarów pozaborowych); charakter oświatowy (co oznaczało edukację dorosłych rzesz robotników); charakter kulturalny (w szerokim znaczeniu). Organizacja miała być silna, co prognozowało wysoką wartość i skuteczność jej oddziaływań oraz umożliwiało docieranie do dużych grup robotników i ich rodzin. Piwowarczyk w tej kwestii pisał: „Na obóz katolicki spada obowiązek stworzenia silnej i jednolitej organizacji oświatowo-kulturalnej robotników. Poza Wielkopolską, gdzie działa coraz intensywniej odrodzony po wojnie «Związek robotników katolickich», poza kilkoma miastami wb. zaborze rosyjskim, gdzie istnieje «Stowarzyszenie chrześcijańskich robotników», ujętej w ścisłe ramy organizacyjne, takiej katolickiej akcji oświatowej wśród robotników nie ma"62. Projekt ten w swym wymiarze pedagogicznym wchodzi w zakres wychowania społecznego dorosłych, a w zakresie treści edukacyjnych lub wychowawczych stanowi dziedzinę wychowania obywatelskiego i politycznego.

Wychowanie społeczne w sensie ścisłym obejmuje także problemy wychowania w rodzinie; jego społeczno-ekonomiczne uwarunkowania zajmowały (oprócz wielu wyżej wymienionych) Stefana Wyszyńskiego. Najszerzej odnosił się do zmian w kulturze, odbijających swoje piętno na kondycji człowieka ido ogromu zła

\footnotetext{
${ }^{60}$ Kostkiewicz, Kierunki, 431-432.

61 Theiss, Troska i nadzieja.

${ }^{62}$ Jan Piwowarczyk, Oddziaływanie dzisiejszych stosunków w świecie pracy na życie moralne i religïne robotnika (Kraków: Nakł. Związku Katolickich Stowarzyszeń Robotników Diecezji Krakowskiej 1926), 14.
} 
powodowanego bezrobociem w sferach robotniczych ${ }^{63}$. Równolegle interesowały go społeczne uwarunkowania życia moralnego i religijnego oraz takiegoż wychowania na polskiej wsi, zubożałej do niewyobrażalnych granic nie tylko wskutek polityki zaborców, ale i władz II Rzeczypospolitej ${ }^{64}$. Sprawy ogólne tej dziedziny, mające swoją reprezentację w pismach Wyszyńskiego, Niesiołowskiego czy Dobrzyńskiej-Rybickiej, to także zainteresowanie młodzieżą: jej rozwojem, aktywnością, perspektywami życiowymi, kulturą, w której żyje i która ją kształtuje ${ }^{65}$. Oddzielnym zagadnieniem była walka z przestępczością powodującą największe cierpienie (handel ludźmi ${ }^{66}$ ) oraz jej przeciwdziałanie.

\subsection{Wychowanie obywatelskie}

Wychowanie obywatelskie obejmuje wychowanie do współdziałania wsferze publicznej dla dobra wspólnego. Jego odmianą, w ujęciu Aleksandra Wóycickiego, jest bez wątpienia wychowanie poprzez naprawę chrześcijańskiego ruchu robotniczego. Wychowanie obywatelskie dotyczy tu robotników, będąc zarówno elementem ich osobistego rozwoju, jak i jednym z warunków budowania n o w y ch form $\dot{z}$ y c i a s p o ł e c z n e g o, których potrzeba była powszechnie odczuwana, na co wskazywał także między innymi Andrzej Niesiołowski ${ }^{67}$. Zarówno nowe formy, jak i struktury życia społecznego dawałyby możliwość obywatelskich działań, postaw, zachowań - co było szczególnie istotne dla młodych wchodzących w życie.

Kształtowania postaw obywatelskich jako wymogu koniecznego i wstępnego wymagała koncepcja Wóycickiego. Szczególnie złożona i wymagająca była ona w sferze współpracy duchownych oraz świeckich: bez postaw obywatelskich osób duchownych, ksztaltowanie ich wśród młodzieży uważał Wóycicki za niemożliwe. Wychowanie obywatelskie, które miałoby się odbywać poprzez naprawę chrześcijańskiego ruchu robotniczego, mieści u swych podstaw wiele wymiarów: ekonomiczny, polityczny, kulturalny; punktem wyjścia czyni więc Wóycicki szeroką i wielowątkową edukację środowisk robotniczych. W koncepcji wychowania przez naprawę chrześcijańskiego ruchu robotniczego uznaje ją za wyjątkowo konieczną z powodu:

«[...] szerzenia się i programowo groźnego socjalizmu i komunizmu oraz bezwzględnego kapitalizmu, gdzie wyzysk robotnika polskiego jest większy niż gdziekolwiek w Europie z powodu obcości kapitału i kapitalistów zagranicznych (nie łączą go z robotnikiem narodowość, ani język, ani religia). Socjaliści mają dobrych przywódców,

${ }^{63}$ Stefan Wyszyński, „Przemiany moralno-religijne pod wpływem bezrobocia”. Ateneum Kaptańskie 39 (1937): 264-276, 382-398, 481-487; 40 (1937): 174-194, 293-301, 393-405, 496-508; tegoż, „Posady dla ojców rodzin". Ateneum Kaptańskie 32 (1933): 302-307.

${ }^{64}$ Tegoż, „Problemy społeczno-moralne wsi w „Pamiętnikach Chłopów”. Ateneum Kaplańskie 41 (1938): 154-169; tegoż, „Wymowa procesów chłopskich”. Ateneum Kaptańskie 32 (1933): 497-506.

${ }^{65}$ Tegoż, „Społeczeństwo i prasa a wychowanie młodzieży”. Ateneum Kapłańskie 32 (1933): 175-188.

${ }^{66}$ Tegoż, „Warszawski Kongres do walki z handlem żywym towarem”. Ateneum Kapłańskie 27 (1931): 175-177.

${ }^{67}$ Jagielska, Kostkiewicz, Pedagogika, 138-187. 
zrzeszenia kulturalne i sportowe dla młodzieży i dzieci, prasę i nawet T.U.R. Słabość robotnika chrześcijańskiego jest ogromna nie tylko z powodu obcości i siły wspomnianych wyżej, ale i ogromnej biedy w Polsce - pisał. Wóycicki kreśli program wsparcia robotników nie tylko w organizacji ich związków zawodowych, które uznaje za niezbędne, ale też zakładania i wspierania stowarzyszeń oświatowo-kulturalnych. Proponuje zrekonstruować Stowarzyszenie Robotników Chrześcijańskich, utworzyć Chrześcijański Uniwersytet Robotniczy i zintensyfikować starania o środki finansowe z Komisji Podziału Kredytów na akcję kulturalno-oświatową z Ministerstwa Opieki Społecznej. Proponuje czynić to z udziałem duchownych, którym taka praca społeczno-oświatowa będzie zlecana przez władze kościelne. Dla biednych robotników proponuje bezpłatną obsługę religijną [chrzty, śluby, pogrzeby]. Proponuje, by Rada Społeczna przy Prymasie Polski opracowała program edukacyjny dla tych celów, który można by realizować za pośrednictwem następujących form: zwołać zjazd kierowników chrześcijańskich związków zawodowych dla zunifikowania różnych jego odłamów, celem bardziej racjonalnego działania; szkolenie kierowników chrześcijańskich związków zawodowych w specjalnie zorganizowanych szkołach w większych i przemysłowych kilku miastach, które prowadziłyby dla kierowników związków zawodowych głównie zimowe kursy 3-6 miesięczne; napisanie podręcznika dla chrześcijańskich związków zawodowych.» ${ }^{68}$

Aleksander Wóycicki bezsprzecznie prowadził działalność pedagoga społecznego: z pełną świadomością nakreślił program pracy wychowawczooświatowej dla struktur Kościoła katolickiego, uzasadniając go zaleceniami wskazanymi w dokumentach, które czyniły prawomocnym ten kierunek działalności; niektórymi przekraczał istniejący w Kościele ówczesnym stosunek do kwestii robotniczych w tym obszarze.

Wychowanie przez naprawę ruchu robotniczego i elementy wychowania do sprawiedliwości społecznej (jako elementarnego wyrazu obywatelskości) propagował także ksiądz Jan Piwowarczyk. Swoimi wykładami i odczytami promował taki rodzaj wychowania obywatelskiego, który zawiera w sobie także wychowanie polityczne: obydwie dziedziny postrzegał jako ważne dla utrzymania niepodległej państwowości. Pisał: „Lud nasz w mieście i na wsi jest zbudzony do życia państwowego, ale nie wychowany. Zostaje pod wpływem agitacji klasowej. Nie można pozwolić, by ten stan się utrzymywał. Grozi on bowiem rozpętaniem burzy podobnej do tej, którą Rosja w 1917 r. przeszła. Lud ten trzeba pojednać ze społeczeństwem, nauczyć go myśleć kategoriami całości, państwa, narodu, należy go wychować." ${ }^{\prime 9}$

Wychowanie obywatelskie obejmuje też wychowanie do życia w państwie, o którym pisał Ignacy Czuma, nie stawiając jednak wychowania państwowego przed narodowym. Podejmował on kwestie bytu podmiotowego jednostki i narodu jako

\footnotetext{
${ }^{68}$ Kostkiewicz, Kierunki, 437-438.

${ }^{69}$ Jan Piwowarczyk, Inteligencja a ruch chrześcijańsko-społeczny (Poznań: Księgarnia św. Wojciecha, odb. z Przewodnika Społecznego 1926: 12).
} 
naturalnej grupy społecznej, ich wolności oraz faktycznego urzeczywistnienia; zagadnienia te jednocześnie wchodzą w skład wychowania politycznego.

\subsection{Wychowanie polityczne}

Dla dorosłego człowieka oraz dla społeczeństwa dziedzina ta jest niezbywalna w rozumieniu zjawisk i procesów przebiegających w świecie. Wóycicki potwierdza świadomość tej potrzeby, gdy kreśli mechanizm oddziaływania ideologii kreujących właściwe sobie modele człowieka i społeczeństw w ówczesnej kulturze oraz edukacji. Przeciwstawia sobie dwie ideologie (dwa projekty polityczne) zawierające odmienne koncepcje człowieka i stojące za nimi programy wychowania (celem samego przeciwstawienia jest trzecia droga polityczna):

«[...] pierwsza to „tak zwany dzisiaj homo sovieticus - człowiek sowiecki, komunista; druga, znana pod nazwą homo europaeus - to człowiek europejski"70 Ani ekonomia, ani sprawa podziału bogactw nie jest celem rewolucji marksistowskiej w Sowietach, celem tym jest całkiem nowy człowiek - komunista (który jest zupełnie nowym ludzkim tworem, i jako taki właśnie musi dowieść odmienności i swego istnienia) - twierdzi Wóycicki. Ta idea przewodnia, współgrając z założeniem mówiącym, że „materia jest jedyną tylko rzeczywistością, jej to musi podporządkować się wszelki wysiłek człowieka. Wychować człowieka to znaczy w y c ho w a ć w y t wó r c ę [wyr. - JK]"71 - komentuje Wóycicki. Każde poznania prowadzące do wiedzy ma swój cel - więcej i lepiej wytwarzać. Ponieważ Wóycicki zakłada, że człowiek nie może żyć bez żadnej szlachetnej idei, co uznaje za powszechną wiedzę, „musiano dodać pedagogii sowieckiej i całemu systemowi poddania człowieka pod jarzmo produkcji promienny cel pewnej mistyki. Polega ona [(..) na tym, że - JK] ludzkość dzisiejszą zaprzęga się w niewolę wytwarzania celem wyzwolenia z jarzma wytwarzania ludzkości jutrzejszej. Dziecko przyucza się do poświęcenia się dla przyszłego raju ziemskiego, którego ono samo nie zobaczy."72 Całą kreację nowego człowieka - razem z zastosowanymi po drodze drakońskimi środkami do tego służącymi - podtrzymuje się na tej idei zastępującej kiepskim falsyfikatem mistykę (spirytualizm) chrześcijańską - twierdzi Wóycicki.

Druga koncepcja homo europaeus wpisana jest w cywilizację łacińską została „zromanizowana, uchrześcijaniona i pod względem umysłowym ulega dyscyplinie greckiej, bezwzględnie jest europejska", ${ }^{73}$ a człowiek nie jest tu narzędziem. Na jej tle Wóycicki podkreśla potrzebę powrotu do pojęcia „osoby”. Kształtowanie jej opiera na dwu

${ }^{70}$ Aleksander Wóycicki, „Podstawy wychowania moralnego”, w: Siły moralne wspólne wszystkim ludziom, ich źródla irozwój przez wychowanie. Referaty VI-go Międzynarodowego Kongresu Wychowania Moralnego w Krakowie, praca zbiorowa (Kraków: Wydane staraniem Komitetu Organizacyjnego VI-go Międzynarodowego Kongresu Wychowania Moralnego 1934), 285-286.

${ }^{71}$ Tamże, 287.

72 Tamże, 288. Zdaniem Wóycickiego materializm ten zjednej strony spokrewnia się z liberalizmem ekonomicznym, z drugiej z naturalizmem jako teorią mówiącą o człowieku z natury dobrym (tamże).

${ }^{73}$ Wóycicki, Podstawy, 290. 
zasadniczych prawdach. Pierwsza - w zakresie wychowania moralnego - nakazuje odwoływać się do prawa moralnego będącego przejawem rozumnej natury ludzkiej, zwanego prawem przyrodzonym. Tu uznaje, że człowiek posiadający rozumną naturę, ma swój cel do urzeczywistnienia. Wóycicki ujmuje to tak: ,natura, acz w swej budowie zupełna, nie ma wszystkiego, co pragnęłaby posiadać: że pewna doskonałość uzupełniająca, uważana za dobro najwyższe, ponad które nie ma już nic do pragnienia, może ją wzbogacić, i że te j d o s k o n a ł o ś c i [wyr. -JK] człowiek wyczekuje"74. To pragnienie utożsamia Wóycicki z ludzkim pragnieniem szczęścia. Uznanie rozumnej natury ludzkiej jako podstawy wychowania moralnego, prowokuje pytanie: dlaczego człowiek powinien dążyć do szczęścia rozumianego jako jego doskonałość osobowa? Pośrednią próbę odpowiedzi typu: bo takie jest prawo naszej natury - Wóycicki uznaje za niewystarczającą. Stawia pytanie o to, kto jest prawodawcą? Jego zdaniem odnalezienie Go nakazuje „uciec się do Najwyższego Rozumu, który, [...] wskazał tej naturze cel, ku jakiemu ma ona dążyć i zaznaczył obowiązek do spełnienia. Prawodawca - to Bóg, który nadał prawo naturze człowieczej." 75 Niejako w tle lokuje drogi realizacji prawa moralnego i wychowania według nakazu Prawodawcy.» ${ }^{76}$

Teksty Wóycickiego wychowywały politycznie. Ich forma i treść miały niejednokrotnie charakter demaskatorski, perswazyjny, a podejmowane polemiki i ich źródła mogły zjednywać zwolenników. Na przykład Wóycicki:

«podważa głoszoną przez socjalistów tezę o ich tolerancji względem religii (ponadto założenie, że religia jest rzeczą prywatną każdej jednostki) jako nieprawdziwą. O szerzonym socjalizmie i komunizmie w postaci akcji Międzynarodówki Komunistycznej, Wóycicki pisze: „Do usunięcia tego dziś najgroźniejszego wroga Kościoła i Polski trzeba koniecznie stworzyć nowy typ kapłana o wysokim urobieniu wewnętrznym, gorliwości apostolskiej i wszechstronnym wykształceniu, zwłaszcza społecznym. [...] towarzyszyć jej musi praca poza kościelna, katolicko-społeczna [...]. Ale zorganizować i prowadzić nasze katolickie społeczeństwo sami księża nie zdołają. Muszą tu przyjść z pomocą szeregi katolików świeckich" [(...)Z przykrością stwierdza, że nie nadaje się do tego polski inteligent, bo w swej zasadniczej masie jest on $-\mathrm{JK}]$ produktem szkoły niepolskiej i niekatolickiej”" ${ }^{\prime 77}{ }^{78}$

W dwudziestoleciu międzywojennym także młody Stefan Wyszyński publikował teksty, które, wskazując na zakres zainteresowań katolickiej nauki społecznej, zawierały elementy wychowania politycznego i uzasadnienie uprawnień Kościoła do działalności w tym zakresie, wynikających z osadzenia na podstawach moralnych życia publicznego, kapitału i pracy. Wyszyński mówił, że „stosunki

\footnotetext{
${ }^{74}$ Tamże, 292.

${ }^{75}$ Tamże, 295.

${ }^{76}$ Kostkiewicz, Kierunki, 433-434.

${ }^{77}$ Aleksander Wóycicki, Socjalizm a religia. Studjum socjologiczne (Poznań-Warszawa: Nakł. Księgarni św. Wojciecha [b.r.w.]), 76-77.

${ }^{78}$ Kostkiewicz, Kierunki, 437.
} 
społeczne ludzi, pracodawców i robotników, właścicieli, sprzedawców i nabywców, wytwórców i spożywców nie są wolne od kontroli i moralnej oceny sumienia"79.

W kwestii stosunków społecznych Kościołowi wypada rola stróża moralności zarówno indywidualnej, jak i społecznej we wszelkich jej dziedzinach. Zgodnie z katolicką nauką społeczną winien on być stróżem sprawiedliwości oraz miłości w obszarze społecznym i gospodarczym, nie będąc żadną ze stron. Granice tego oddziaływania wytyczane są za pomocą kryterium religijnego, jednak kiedy sprawy bytowe człowieka nie pozwalają mu na życie zgodne z moralnością (kradzież z głodu, bezrobocie, ciasnota mieszkaniowa, nadmierna, wyniszczająca praca niedająca godziwej zapłaty, naruszająca godność, czyniąca życie nieznośnym itp.) - Kościół ma obowiązek interweniować; może też i powinien komunikować swój osąd, wskazać błąd, wezwać do zmiany ${ }^{80}$.

Wyszyński jako młody kapłan wielokrotnie wypowiadał się prospołecznie: przeciw aferom bankowym, dyskryminującym płacom, niesprawiedliwemu podziałowi wypracowanych dóbr ${ }^{81}$. Rzecz dotyczyła także doktryn (ideologii) wszelkiego rodzaju, w tym społecznych i ekonomicznych: Kościół nie zajmował się nimi samymi, lecz komentował wywieranie przez nie wpływu $\mathrm{n}$ a c z ł o w i e k a, jego sferę moralną i religijną (także poprzez życie i wychowanie społeczno-gospodarcze): „Kościół musi zająć się oceną wartości tego wpływu”82.

Podobne znaczenie wzakresie wychowania politycznego miały teksty Antoniego Szymańskiego. W atmosferze lat trzydziestych odnosi się to szczególnie do tych zawierających krytykę wizji człowieka i jego wychowania wsystemach totalitarnych (komunizmie i narodowym socjalizmie) ${ }^{83}$. Publikowana krytyka ówczesnych ideologii ,grających” o człowieka, połączona z organizowanymi corocznie Tygodniami Społecznymi w KUL (w których brała udział studencka i naukowa młodzież katolicka), stanowiła wielkie przedsięwzięcie edukacyjne. W tym środowisku wychowała się grupa, której efekty pracy i życia pozostawily znaczący ślad. Same „Tygodnie Społeczne” w KUL miały charakter edukacji społeczno-politycznej dla młodzieży środowisk akademickich i należały do wyczekiwanych wydarzeń.

Podsumowując należy podkreślić, że wychowanie polityczne jako dziedzina wychowania społecznego często dochodziło do głosu w podobny sposób, w jaki je rozumiała katolicka nauka społeczna. W Polsce międzywojennej było ono w swej treści aktualne i respektowało prawo człowieka do rozumienia procesów dziejowych oraz uczestniczenia w nich poprzez działania i zachowania obywatelskie ( $w$ tamtym

\footnotetext{
${ }^{79}$ Kodeks Spoleczny, wyd. II (Lublin, KUL, 35), za: Stefan Wyszyński, „Zasięg i charakter zainteresowań katolickiej myśli społecznej”, w: Katolicka myśl społeczna, 52.

${ }^{80}$ Wyszyński, Zasięg i charakter, 53-54.

${ }^{81}$ Tegoż, „Głos Episkopatu o ducha chrześcijańskiego w Polsce a opinia publiczna”. Ateneum Kaptańskie 33 (1934): 385-396.

82 Tegoż, Zasięg i charakter, 56 .

${ }^{83}$ Antoni Szymański, „Bolszewizm jako prąd kulturalny i cywilizacyjny”. Prąd 32 (1937): 207-242. Tę część twórczości A. Szymańskiego analizuję w: Kostkiewicz, „Krytyka”, 439-455.
} 
okresie w pedagogice katolickiej ksiądz Zygmunt Bielawski opracowywał etapy wychowania do czynu). Propagatorzy wychowania politycznego wyrażali obawy o losy świata zawłaszczonego przez twórców totalitarnych ideologii i polityków; świata zaprzepaszczonego rozwoju duchowego na rzecz materialnego, który nigdzie nie przyniósł ani harmonii życia, ani szczęścia ${ }^{84}$. Istota programów wychowania politycznego twórców katolickiej nauki społecznej kryje się w motywie przewodnim jednego z tekstów: „Kto chce uniknąć rewolucji, musi chcieć reform, a pośród nich reformy dotychczasowego wychowania w duchu naprawy poglądu, sumienia i serca obywatela" ${ }^{25}$.

\section{Organizacje, związki i stowarzyszenia jako formy wychowawczego oddziaływania społecznego}

$\mathrm{Na}$ początku należy przypomnieć, że dla wdrażania katolickiej nauki społecznej i efektywnego wychowania, de facto według humanistycznej pedagogiki społecznej, tworzono różnorodne formy organizacyjne. Ich inspiratorem był Kościół oraz świeccy katolicy. W obrębie Kościoła działało w omawianym okresie szczególnie wiele organizacji oraz stowarzyszeń dorosłych, młodzieży (w tym studenckich) i dzieci; ich zasięg, a także rola były zróżnicowane. Z reguły charakteryzowały się tym, że posiadały oryginalne i wartościowe programy wychowawcze. Wśród nich wymienić można takie organizacje, jak:

A k c ja Kat o li c k a - jej struktury założone zostały odgórnie z inicjatywy Papieża. W Polsce kierował nią biskup Stanisław Adamski, a Naczelny Instytut Akcji Katolickiej, prowadzący działalność wydawniczą, znajdował się w Poznaniu. Na uwagę zasługują serie wydawnicze, takie jak: „Studia Katolickie”, „Biblioteczka Akcji Katolickiej”, „Kultura Katolicka” - w latach trzydziestych XX wieku serie te liczyły już po kilkanaście tomów. Akcja posiadała własne pismo: „Ruch Katolicki”. Wychowaniem społecznym starano się objąć różne grupy wiekowe i środowiska, skupiano także uwagę na młodzieży akademickiej ${ }^{86}$.

R u ch s pół d z i el c z y - wspierany był przez Kościół i stanowił nie tylko remedium na polepszenie sytuacji ekonomicznej, ale także czynnik rozwoju kulturowego społeczeństwa. Jednym z jego prekursorów na terenie Polski był ksiądz Stanisław Staszic, który w roku 1816 założył Towarzystwo Rolnicze Hrubieszowskie. Ruch spółdzielczy rozwijał się pod zaborami, by w dwudziestoleciu międzywojennym stać się istotną formą wychowania obywatelskiego i edukacji dorosłych. Znane są jego wielkie osiągnięcia, do których należały między innymi Wielkopolskie Kasy Stefczyka, kółka rolnicze i dziesiątki innych spółdzielni (najmocniej promowane były

\footnotetext{
${ }^{84}$ Wóycicki, Podstawy wychowania, 295 i dalej.

${ }^{85}$ Tegoż, Rola wychowania $w$ naprawie, 432.

${ }^{86}$ Franciszek Marlewski, „Akcja Katolicka w służbie wychowania społecznego”. Ruch Katolicki 8 (1938), 347-358; Bonifacja Wernerówna O.S.U., „Postulat społecznego wychowania młodzieży”. Ateneum Kaptańskie 41 (1938): 370-381; Stefan Wojsa, „Hasła katolicko-społeczne w życiu młodzieży akademickiej”, Ateneum Kaplańskie 28 (1931): 282-286.
} 
w miejskim budownictwie mieszkaniowym i rolnictwie). Spółdzielczość (kooperatywa) zaznaczała swą obecność w strukturach lokalnych oraz wydawała broszury. Powszechnie przypisywano jej przede wszystkim ogromne znaczenie wychowawcze: „Bowiem by być spółdzielcą nie wystarczy umieć uprawiać handel, trzeba jeszcze mieć ideały. Celem moralnym społecznego ruchu spółdzielczego jest: wyszkolenie, wychowanie i przekształcenie, bezmyślnego i bezradnego tłumu w warstwę społeczną, myślącą i zaradną. Spółdzielczość (kooperatywa), oprócz korzyści gospodarczych, posiada doniosłą rolę moralną: z jednej strony jest praktycznym narzędziem do zaszczepiania cnót społecznych, z drugiej tępienia wad (np. alkoholizm był przeszkodą w przyjmowaniu do spółdzielni)"\$7.

Cel ekonomiczny wynikał z prób reagowania na wyzysk, poczucie niesprawiedliwości przy podziale zysku czy niesprawiedliwe ceny. Spółdzielczość nie tylko chroniła ekonomicznie, ale i wychowywała społeczeństwo, podnosząc jego morale. W ruchu spółdzielczym popierano oświatę ludu, konieczna też była aktywność, co stanowiło zatem szkołę życia publicznego ${ }^{88}$. Twierdząc że ówczesny ruch spółdzielczy idzie trzema drogami: liberalną, chrześcijańską i socjalistyczną, wskazuje Wóycicki podstawowe różnice między nimi. W chrześcijańskim światopoglądzie społeczeństwo jest bytem moralnym, jest organizacją złożoną z jednostek wolnych, jest bytem stworzonym przez Boga dla ich wszechstronnego rozwoju. Z kolei jednostki swoją energią mogą potężnie oddziaływać na jego dobro ${ }^{89}$. Codzienne życie kooperatywy, jak pisał Wóycicki, pozwalało wprowadzać w czyn miłość bliźniego, zasadę zgody i sprawiedliwości - jako elementy nauki Jezusa ${ }^{90}$.

Sodalicja Mariańska - obejmowała swym oddziaływaniem przede wszystkim wychowanie religijne i moralne, postrzegane jako fundament wychowania społecznego. Sodalicje cieszyły się szerokim zainteresowaniem, szczególnie w szkołach średnich wszelkich typów. Przeprowadzano nawet badania sondażowe dotyczące spełniania oczekiwań młodzieży w nauczaniu Kościoła ${ }^{91}$.

Stowarzyszenie Katolickiej Młodzieży Akademickiej „Juwentus Christiana" - powstało w 1921 roku z inicjatywy Aleksandra kardynała Kakowskiego. Działalność (zorganizowana w małych grupach - kołach) miała formę pracy seminaryjnej, polegającej na czytaniu i dyskusji połączonej z formułowaniem reguł o charakterze wychowawczym dla pracy i życia codziennego $0^{92}$.

Stowarzyszenie Katolickiej Młodzieży Akademickiej "Odrodzeni e" - jego początki sięgają roku 1919, pierwsze koła powstały w War-

87 Aleksander Wóycicki, „Moralne znaczenie spółdzielczości. Referat wygłoszony na zjeździe przedstawicieli spółdzielni chrześcijańskich w Warszawie dn. 24 czerwca 1923 r.”. (Warszawa: Nakł. Centrali Spożywczych Stow. Spółdz. Rob. Chrz., 1923), 6. Cyt. za: Kostkiewicz, Kierunki, 436.

${ }^{88}$ Tamże, 13 .

${ }^{89}$ Tamże, 18-19.

${ }^{90}$ Kostkiewicz, Kierunki, 437.

91 Tadeusz Długosz, „Rekolekcje w ocenie młodzieży”. Miesięcznik Katechetyczny i Wychowawczy 7 (1928): 329-334; 9 (1928): 432-435. J. Winkowski, Ustawy Sodalicji Mariańskiej Młodzieży Szkót Średnich $w$ Polsce (Warszawa: Nakładem Związku Sod. Maryji szkół średnich 1920).

${ }^{92}$ Marian Niwiński, „Iuventus Christiana”. Przegląd Powszechny 194 (1932). 
szawie, Lublinie, Poznaniu i Wilnie. Współpracowało z Akcją Katolicką, wydawało kilka pism; do bardziej znaczących należą „Prąd”, „Świat Akademicki”, „Odrodzenie”. Szerokie oddziaływanie miały współorgani-zowane przez Stowarzyszenie we współpracy z władzami KUL „Tygodnie Społeczne” (o charakterze naukowym i kulturalnym); gromadziły młodzież akademicką, odbijały się też szerokim echem w kraju. Istotnym odgałęzieniem Stowarzyszenia był Chrześcijański Związek Młodzieży Pracującej „Odrodzenie”, który powstał w wyniku potrzeby wyjścia poza środowisko akademickie. Utworzony w latach 1926/27 zrzeszał młodzież pracującą; jako organizacja samodzielna współpracował ze swym akademickim odpowiednikiem.

H a r cerstwo - jako ruch społeczno-wychowawczy w dwudziestoleciu międzywojennym działało poprzez szereg swoich odmian i ich organizacji. W swym podstawowym nurcie odwoływało się wówczas do religii katolickiej ${ }^{93}$. Samodoskonalenie (praca nad sobą), braterstwo i służba społeczeństwu oraz Ojczyźnie były jego podstawowymi zasadami ${ }^{94}$.

Związki z aw od owe - ruch związkowy inspirowany katolicką nauką społeczną nie był ujednolicony ani w Europie, ani w Polsce, a w piśmiennictwie odnotowuje się ogromną liczbę związków. Potrzebę ich zakładania i aktywność w tym zakresie wykazywali głównie Aleksander Wóycicki, Andrzej Niesiołowski oraz Antoni Roszkowski opisujący Światową organizację robotników Chrześcijańskich ${ }^{95}$.

Działalność stowarzyszeń, związków i różnorodnych organizacji opisywana była między innymi przez księdza Franciszka Marlewskiego i siostrę Bonifację Wernerównę; na łamach pism katolickich oraz samodzielnych opracowań omawiano ustawy i uchwały poszczególnych stowarzyszeń. Eksponując ich istotę, cele, środki, charakteryzując promowany profil członka, zapowiadano rodzaj pracy społecznej oraz nad kształtowaniem własnego charakteru. Udostępniano zainteresowanym działalność zarządu, opisywano ceremoniał, zamieszczano także relacje ze zjazdów. W ośrodkach akademickich zakładano jednostki organizacyjne zajmujące się badaniem tej problematyki: na Wydziale Teologicznym Uniwersytetu Jagiellońskiego od roku 1908 istniała Katedra Chrześcijańskich Nauk Społecznych kierowana przez księdza profesora Kazimierza Zimmermanna. W 1926 roku ksiądz Edward Kozłowski założył w Poznaniu Katolicką Szkołę Społeczną, a w „Przewodniku Społecznym” publikował teksty na temat teorii i praktyki katolickiej nauki społecznej ${ }^{96}$.

\footnotetext{
${ }^{93}$ Wacław Malinowski, „Harcerstwo w służbie Bogu i Polsce”. Miesięcznik Katechetyczny i Wychowawczy 6 (1936): 291-297; Józef Młodochowski, „Harcerstwo”. Miesięcznik Katechetyczny i Wychowawczy 8 (1928): 369-382; 9 (1928): 417-32.

${ }^{94} \mathrm{O}$ harcerstwie jako ruchu katolickim szerzej piszę w: Kostkiewicz, Kierunki, 636-642. Zob. przede wszystkim: Bogusław Śliwerski, Przyrzeczenie harcerskie. Historia, metodyka, manipulacje (Kraków: Oficyna Wydawnicza „Impuls”, 2009).

95 Antoni Roszkowski, „Światowa organizacja robotników Chrześcijańskich M.K.Ch.Z.Z.”. Ateneum Kaplańskie 23 (1929): 86-94.

${ }^{96}$ Jan Hellwig, „W kręgu refleksji nad pedagogiką katolicką. Ksiądz Julian Młynarczyk (1882-1950)”, w: Człowiek - moralność - wychowanie, dz. cyt., 275.
} 


\section{Podsumowanie}

Wskazani tu intelektualiści i działacze społeczni stworzyli ogromnie szeroki „praktyczny i jednolity program zarówno polityki społecznej, jak i przemian ustrojowych" w Polsce. Ich pisma (zarówno prace naukowe, jak i publicystyka) or az działalność praktyczna pokazały nowe pola pracy społeczno-pedagogicznej. Podstawą była przede wszystkim edukacja dorosłych oraz młodzieży z wszystkich warstw społecznych, a formą pracy aktywność organizacji i stowarzyszeń dla dorosłych, studentów, młodzieży szkolnej, dzieci; także działalność w związkach zawodowych i partiach politycznych. W dwudziestoleciu międzywojennym Kościół katolicki był zaangażowany w tę działalność zarówno w jej warstwie teoretycznej, jak i praktycznej.

Humanistyczna pedagogika społeczna powstająca równolegle $\mathrm{z}$ katolicką nauką społeczną (w jej obrębie, na pograniczu lub w pewnej bliskości) niejako „wpisana” jest w jej warstwę teoretyczną, której podstawę stanowią teksty wspólne dla niej i katolickiej nauki społecznej (oddzielenie tekstów pedagogicznych od socjologicznych bądź socjologiczno-teologicznych ani nie jest łatwe, ani często możliwe ze względu na ich interdyscyplinarność). Wprowadzanie katolickiej nauki społecznej w czyn - jej głoszenie i podejmowanie działań praktycznych przez nią promowanych - jest $\mathrm{w}$ istocie nieformalnym procesem wychowawczym, czasem tylko edukacyjnym. Już samo wskazanie podmiotów działających w tym obszarze odsłania polskie tradycje wychowania społecznego, co ma wartość historyczną oraz znaczenie jako wzorzec, który może być twórczo kontynuowany.

Streszczenie: Celem artykułu jest uczynienie kroku w kierunku przywrócenia pedagogice społecznej obszaru teorii i praktyki wychowawczej, który powstał na pograniczu pedagogiki i katolickiej nauki społecznej. Stanowi on humanistyczną pedagogikę społeczną. Działanie to ma sens, bowiem diagnoza stanu syntez i opracowań pedagogiki społecznej mówi o zagubieniu wkładu pedagogów w tę pedagogikę, zarazem w teorię i praktykę życia społecznego oraz kultury narodowej. Wkład ten wymyka się nie tylko historykom wychowania, ale i współczesnemu dyskursowi pedagogicznemu odbywającemu się z pominięciem tego dorobku, jego tradycji i wagi. Po niniejszym szkicu interpretacji zagadnienia humanistyczna pedagogika społeczna oczekuje na pełną rekonstrukcję.

Słowa kluczowe: humanistyczna pedagogika społeczna, dziedziny wychowania, twórcy pedagogiki społecznej, wychowanie społeczne, wychowanie obywatelskie, wychowanie polityczne, pedagogika pogranicza

\footnotetext{
${ }^{97}$ Stanisław Wawryn, „Inteligencja a przebudowa ustroju”. Prąd 7 (1935): 75.
} 


\section{Bibliografia}

Adamski Stanisław. „Parafialna Akcja Katolicka”. Ruch Katolicki 1 (1938).

Adamski Stanisław. Podstawy pracy Stowarzyszeń Akcji Katolickiej, Poznań: Naczelny Instytut Akcji Katolickiej (dalej NIAK), 1937.

Adamski Stanisław. Szkoła wedle nauki Kościoła i uchwat Synodu. Poznań: NIAK, 1939.

Cichosz, Mariusz. Pedagogika społeczna. Zarys problematyki. Kraków: Oficyna Wydawnicza „Impuls”, 2014.

Czuma Ignacy. Polityka ludnościowa III Rzeszy. Lublin: Towarzystwo Naukowe KUL, 1939.

Czuma, Ignacy. „Sprawiedliwość i miłość jako zasady chrześcijańskiego ustroju społecznego”, w: Katolicka myśl spoleczna. Pamiętnik III Studium Katolickiego w Warszawie 5 - 10.IX.'37, 130-147. Poznań: NIAK, 1938.

Czuma, Ignacy. „Wolność narodu w państwie”. Prąd 37 (1939): 220-238.

Czuma, Ignacy. Filozoficzne punkty styczne zachodu i bolszewizmu. Lublin: Drukarnia Narodowa, 1930.

Dobrzyńska-Rybicka, Ludwika. „Czynniki wychowania moralnego w pracy zbiorowej”, w: Sity moralne wspólne wszystkim ludziom, ich źródta i rozwój przez wychowanie. Referaty VI Międzynarodowego Kongresu Wychowania Moralnego. Kraków: Komitet Organizacyjny VI-go Międzynarodowego Kongresu Wychowania Moralnego1934.

Dobrzyńska-Rybicka, Ludwika. „Wychowanie państwowe”, w: Katolicka myśl wychowawcza. Pamiętnik II Studium Katolickiego w Wilnie $w$ dn. 28.VIII - 1. IX. 1936r. Poznań: NIAK, 1937.

Dobrzyńska-Rybicka, Ludwika. „Wyzwolenie człowieka jako zagadnienie wychowawcze”. Kwartalnik Pedagogiczny R VII 2-3 (1935): 81-95.

Dobrzyńska-Rybicka, Ludwika. „Zadania świata kobiecego wobec kryzysu rodziny”, w: Rodzina. Pamiętnik I Katolickiego Studium o Rodzinie w Poznaniu, w dn. 2-6 września 1935. Poznań: NIAK, 1936.

Dobrzyńska-Rybicka, Ludwika. Chwila obecna. Próba analizy psychologiczno-etycznej. Poznań: Księgarnia św. Wojciecha, 1922.

Górski, Karol. „Sprawiedliwość i miłość w życiu społecznem”. Prąd 17 (1929): 187-196.

Górski, Ludwik. „Katolicyzm społeczny”. Ateneum Kaptańskie 16 (1919-1925): 33-48.

Jagielska Dominika, Kostkiewicz, Janina. Pedagogika humanizmu społecznego Andrzeja Niesiołowskiego. Kraków: Wydawnictwo UJ, 2015.

Koneczny, Feliks. „Kościół w Polsce wobec cywilizacji”. Ateneum Kaptańskie 22 (1928): 413-429.

Kostkiewicz Janina, Krankus Milan, Podmanický Ivan, Potočárova Maria. Wychowanie - rodzina społeczny rozwój osoby. Studia ze spotkań krakowsko - bratystawskich. Výchova - Rodina - Sociálny rozvoj osoby. Štúdie zo stretnutí krakowsko-bratislavských. Kraków: Wydawnictwo UJ, 2015.

Kostkiewicz, Janina. „Krytyka warstwy wychowawczej totalitaryzmu komunistycznego lat dwudziestych i trzydziestych XX wieku w pismach Antoniego Szymańskiego”. W: W stużbie nauki, wychowania i wartości. Szkice biograficzne o lubelskim środowisku naukowym, red. R. Skrzyniarz, M. Łobacz, B. Borowska, 439-455. Lublin: Wydawnictwo „Episteme”, 2015.

Kostkiewicz, Janina. Kierunki i koncepcje pedagogiki katolickiej w Polsce 1918-1939. Kraków: Oficyna Wydawnicza „Impuls”, 2013.

Kowalczyk, Stanisław. „Humanizm”, w: Powszechna encyklopedia filozofii, t. 4, red. Andrzej Maryniarczyk i in., 655-656. Lublin: Polskie Towarzystwo Tomasza z Akwinu, 2003.

Kowalski, Kazimierz. Nauki rekolekcyjne o Akcji Katolickiej. Poznań: NIAK, 1934. 
Kowalski, Kazimierz. Katolickie plany reformy spolecznej a ustrój rolny w Polsce. Poznań: Biblioteka Akcji Katolickiej nr 8, 1938.

Krotoski, Kazimierz. „Kultura i lojalność obywatelska jako przedmiot wychowania młodzieży”. Przegląd Powszechny 143 (1919): 53-59; 144 (1919): 151-161.

Majka, Józef. Filozofia społeczna. Wrocław: Wydawnictwo Wrocławskiej Księgarni Archidiecezjalnej, 1982.

Malinowski, Wacław. „Harcerstwo w służbie Bogu i Polsce”. Miesięcznik Katechetyczny i Wychowawczy 6 (1936): 291-297.

Niesiołowski, Andrzej. „Sprawa koordynacji katolickiego ruchu społecznego”. Przewodnik Społeczny 1 (1929): 1-7; dokończenie: 2 (1929): 49-55.

Niesiołowski, Andrzej. „Problemat konsumenta kulturalnego i polityki kulturalnej”. Kultura i Wychowanie 3 (1936): 1-16.

Niesiołowski, Andrzej. Koła oświatowo-wychowawcze. Zadania - teoria - wskazania praktyczne. Poznań: Księgarnia św. Wojciecha, 1939.

Niesiołowski, Andrzej. Metody realizacji wychowania społecznego. Poznań: NIAK, 1936.

Ożóg, Tomasz. „J. Maritaina koncepcja wychowania człowieka”. Roczniki Nauk Spolecznych KUL 2 (1993): 6-19.

Pelczarski, Kazimierz. Działalność wychowawcza o. Mariana Pirożyńskiego (1899-1964). Lublin: Towarzystwo Naukowe KUL, 2006.

Pirożyński, Marian. „Udział kapłana w reformie społecznej”. Homo Dei 8 (1939): 102-114.

Pirożyński, Marian. „Wychowawca młodzieży”. Homo Dei 8 (1939): 223-228.

Pirożyński, Marian. „Wynurzenia bezrobotnego”. Homo Dei 7 (1938).

Piwowarczyk, Jan. „Przyszłość myśli katolicko-społecznej i warunki jej realizacji w Polsce”, w: Katolicka myśl spoleczna. Pamiętnik III Katolickiego Studium w Warszawie, 173-192. Poznań: NIAK, 1938.

Piwowarczyk, Jan. Inteligencja a ruch chrześcijańsko-spoleczny. Poznań: Księgarnia św. Wojciecha, 1926.

Piwowarczyk, Jan. Wspótczesne kierunki społeczne. Kraków: Nakł. Związku Katolickich Stowarzyszeń Robotników Diecezji Krakowskiej, 1927.

Rembierz, Marek. „Sensus catholicus: uniwersalizm, obiektywizm, realizm. Myśl filozoficzn-teologiczna i działalność pedagogiczno-duszpasterska Jacka Woronieckiego OP w rozprawach i wspomnieniach Stefana Swieżawskiego”, w: Czlowiek - moralność - wychowanie. Życie i myśl Jacka Woronieckiego $O P$, red. J. Gałkowski, Maurycy L. Niedziela. Lublin: Towarzystwo Naukowe KUL, 2000.

Roszkowski Antoni, „Światowa organizacja robotników Chrześcijańskich M.K.Ch.Z.Z.”. Ateneum Kaplańskie 23 (1929): 86-94.

Roszkowski, Antoni. „Rola Kościoła w rozwiązaniu kwestii społecznej w oświetlaniu encykliki Rerum Novarum". Ateneum Kaptańskie 28 (1931): 429-447.

Rynio, Alina (wybór i przedmowa). Solidarność w nauczaniu Jana Pawła II. Wybór tekstów. Lublin: Instytut Edukacji Narodowej, 2005.

Sawicki, Franciszek, „Założenia filozoficzne katolickiej myśli społecznej”, w: Katolicka myśl społeczna . Pamiętnik III Studium Katolickiego w Warszawie 5-10 IX'37. Poznań: NIAK, 1938.

Sawicki, Franciszek. Fïlozofia życia. Poznań: NIAK, 1936.

Sopoćko, Michal, „Autorytet w rodzinie a wolność dziecka”. Ku Szczytom 3 (1939): 255-261.

Sopoćko, Michał, „Alkoholizm a młodzież szkolna”, w: Księga Pamiątkowa Kursu Katechetycznego w Krakowie (od 9 do 12 kwietnia 1929 R.). Kraków: Nakładem Komitetu Kursu Katechetycznego, 1929. Sopoćko, Michał. O obowiazkach społecznych. Wilno: [b.m.w.] 1931. 
Sułowski, Jan. „Rola wychowania społecznego w przebudowie świata”, w: Katolicka myśl społeczna. Pamiętnik III Studium Katolickiego w Warszawie 5 - 10.IX.'37, 401-413. Poznań: NIAK, 1938.

Szymański, Antoni. „Bolszewizm jako prąd kulturalny i cywilizacyjny”. Prąd 32 (1937): 207-242.

Szymański, Antoni. „Zasadniczy problemat etyki płciowej”. Prąd 18 (1930): 308-317.

Szymański, Antoni. Spoteczne znaczenie rozwodów. Lublin: Towarzystwo Wiedzy Chrześcijańskiej, 1931.

Śliwerski, Bogusław. „Chrześcijańska wizja samowychowania”. Życie Katolickie 7-8 (1986): 139-147.

Śliwerski, Bogusław. Przyrzeczenie harcerskie. Historia, metodyka, manipulacje. Kraków: Oficyna Wydawnicza „Impuls”, 2009.

Święs, Kazimierz. „Społeczna nauka Kościoła”. W: Powszechna encyklopedia filozofii, tom 9, red. Andrzej Maryniarczyk i in., 149-151. Lublin: Polskie Towarzystwo Tomasza z Akwinu, 2008.

Theiss, Wiesław. „Katolicka praca społeczno-wychowawcza. Szkic zagadnienia”. Pedagogika Społeczna 2 (2013): 47-71.

Theiss, Wiesław. Troska inadzieja. Działalność społeczno-wychowawcza ks. Henryka Szumana na Pomorzu w latach 1908-1939. Toruń: Wydawnictwo Adam Marszałek, 2012.

Winkowski, Józef. Ustawy Sodalicji Mariańskiej Młodzieży Szkót Średnich w Polsce. Warszawa: Nakł. Związku Sodalicji Maryji szkół średnich, 1920.

Wojsa, Stefan. „Hasła katolicko-społeczne w życiu młodzieży akademickiej”. Ateneum Kapłańskie 28 (1931): 282-286.

Woroniecki, Jacek. Wychowanie spoleczne i praca społeczna. Warszawa: Biblioteka Prądu, 1921.

Wóycicki, Aleksander. Socjalizm a religia. Studjum socjologiczne. Poznań: Księgarnia św. Wojciecha, [b.r.w.].

Wóycicki, Aleksander. „Rola wychowania w naprawie niesprawiedliwości społecznej”. W: Katolicka myśl wychowawcza. Pamiętnik II Studium Katolickiego $w$ Wilnie $w$ d. 28. VIII - 1. IX. 1936r. Poznań: NIAK, 1937.

Wóycicki, Aleksander. Praca społeczna w parafii. Szkic historyczno-społeczny. Poznań: NIAK, 1937.

Wyszyński, Stefan. „Antyreligijne wychowanie w organizacjach socjalistycznych”. Ateneum Kaptańskie 42 (1938): 485-490.

Wyszyński, Stefan. „Nowe prawo o stowarzyszeniach”. Ateneum Kaptańskie 31 (1933): 55-64.

Wyszyński, Stefan. „Społeczeństwo i prasa a wychowanie młodzieży”. Ateneum Kaplańskie 32 (1933): 175188.

Wyszyński, Stefan. Przemiany moralno-religïne pod wphywem bezrobocia. Włocławek: [b.w.] 1937. 